1

2

3

4

5

6

7

8

9

10

11

12

13

14

15

16

17

18

19

20

21

\title{
Three PilZ domain proteins, PIpA, PixA and PixB, have distinct functions in regulation of motility and development in Myxococcus xanthus
}

Sofya Kuzmich ${ }^{{ }^{*}}$, Dorota Skotnicka ${ }^{{ }^{*}}$, Dobromir Szadkowski ${ }^{\mathrm{a}}$, Philipp Klos ${ }^{\mathrm{a}}$, María PérezBurgos $^{a}$, Eugenia Schander ${ }^{a}$, Dominik Schumacher ${ }^{a} \&$ Lotte Søgaard-Andersen ${ }^{a}$ \#

a Department of Ecophysiology, Max Planck Institute for Terrestrial Microbiology, Karl-von-Frisch Str. 10, 35043 Marburg, Germany

\#Corresponding author

Tel. +49-6421-178 201

Fax +49-6421-178 209

E-mail: sogaard@mpi-marburg.mpg.de

* these authors contributed equally. Author order was determined alphabetically.

Running title: Regulation by PilZ-domain proteins in M. xanthus

Keywords: c-di-GMP, PilZ domain, Myxococcus, type IV pili, gliding motility, chemosensory system, Frz, MglA; fruiting body formation, sporulation 


\section{Abstract}

23 In bacteria, the nucleotide-based second messenger bis-(3'-5')-cyclic dimeric GMP (c-di-

24 GMP) binds to effectors to generate outputs in response to changes in the environment. In Myxococcus xanthus, c-di-GMP regulates type IV pili-dependent motility and the starvationinduced developmental program that results in the formation of spore-filled fruiting bodies; however, little is known about the effectors that bind c-di-GMP. Here, we systematically inactivated all 24 genes encoding PilZ domain-containing proteins, which are among the most common c-di-GMP receptors. We confirm that PIpA, a stand-alone PilZ-domain protein, is specifically important for motility and that Pkn1, which is composed of a Ser/Thr domain and a PilZ domain, is specifically important for development. Moreover, we identify two PilZdomain proteins that have distinct functions in regulating motility and development. PixB, which is composed of two PilZ domains and an acetyltransferase domain, binds c-di-GMP in vitro and regulates type IV pili-dependent and gliding motility upstream of the Frz chemosensory system as well as development. The acetyltransferase domain is required and sufficient for function during growth while all three domains and c-di-GMP binding are essential for PixB function during development. PixA is a response regulator composed of a PilZ domain and a receiver domain, binds c-di-GMP in vitro, and regulates motility downstream of the Frz chemosensory system by setting up the polarity of the two motility systems. Our results support a model whereby the three proteins PIpA, PixA and PixB act in parallel pathways and have distinct functions to regulation of motility.

\section{Importance}

c-di-GMP signaling controls bacterial motility in many bacterial species by binding to downstream effector proteins. Here, we identify two PilZ domain-containing proteins in Myxococcus xanthus that bind c-di-GMP. We show that PixB, which contains two PilZ domains and an acetyltransferase domain, acts upstream of the Frz chemosensory system to regulate motility via the acetyltransferase domain while the intact protein and c-di-GMP binding are essential for PixB to support development. By contrast, PixA acts downstream of the Frz system to regulate motility. Together with previous observations, we conclude that PilZ-domain 


\section{Introduction}

Bacteria have evolved different strategies that allow them to sense and subsequently adapt and differentiate in response to changing environmental conditions. One strategy centers on signaling by a variety of nucleotide-based second messengers (1). The highly versatile second messenger bis-(3'-5')-cyclic dimeric GMP (c-di-GMP) is found widespread in bacteria and is involved in many aspects of bacterial physiology including regulation of motility, adhesion, synthesis of secreted polysaccharides, biofilm formation, cell cycle progression, development, and virulence $(2,3)$.

Signaling by c-di-GMP depends on its regulated synthesis by diguanylate cyclases (DGCs), which contain an enzymatically active GGDEF domain, and degradation by phosphodiesterases (PDEs), which contain either a catalytic EAL or HD-GYP domain (2, 3). Output responses are generated by binding of c-di-GMP to and allosteric regulation of effectors, which direct downstream responses at the transcriptional, translational or posttranslational level $(2,3)$. Several different protein effectors with little sequence homology have been identified and includes enzymatically inactive GGDEF and EAL domain proteins (4-8), PilZ-domain proteins (9-15), MshEN-domain proteins $(16,17)$, members of different transcription factors families as well as a nucleoid-associated DNA binding protein (18-26), and ATPases of flagella, type III and type VI secretion systems (27). The number of DGCs and PDEs encoded by many bacterial genomes typically outnumbers that of known c-diGMP effectors $(2,28)$, thus hampering a detailed understanding of how effects of changing c-di-GMP levels are implemented.

Myxococcus xanthus, a Gram-negative deltaproteobacterium, is a model organism for studying how social behaviors in bacteria can be modulated by environmental cues $(29,30)$. In the presence of nutrients, M. xanthus cells grow, divide and actively move by means of two motility systems to generate colonies in which cells spread outward in a highly coordinated fashion and prey on other microorganisms if present. In response to nutrient depletion, a developmental program is initiated that results in the formation of multicellular, spore-filled fruiting bodies. Both social behaviors depend on regulated motility $(31,32)$ as well as signaling by c-di-GMP (33).

The rod-shaped $M$. xanthus cells move on surfaces in the direction of their long axis using two polarized motility systems and with clearly defined leading and lagging cell poles (31, 32). Gliding motility is favorable on hard and dry surfaces (34) and generally allows the movement of single cells (35). Gliding depends on the Agl/Glt complexes, which assemble at the leading cell pole, attach to the substratum, and disassemble as they reach the lagging cell pole $(36,37)$. By contrast, type IV pili (T4P)-dependent motility is favorable on soft and moist surfaces and mostly occurs in groups of cells $(34,35)$. T4P localize to the leading cell 
pole and undergo cycles of extension, surface adhesion, and retraction to pull cells across surfaces (38-40). Moreover, T4P-dependent motility in $M$. xanthus depends on a secreted exopolysaccharide (EPS) (41-45). The characteristic polarized assembly of the two motility machineries at the leading cell pole only is regulated by a set of four proteins that make up the so-called cell polarity module. The key protein in this module is the small GTPase MgIA, which in its GTP-bound form localizes at the leading cell pole to stimulate assembly of the Agl/Glt complexes as well as formation of T4P (36, 46-49). The activity and localization of MglA is regulated by its cognate Guanine nucleotide Exchange Factor (GEF) composed of the RomR and RomX proteins (50) and its cognate GTPase Activating Protein (GAP) MgIB $(46,49)$. These three proteins localize in bipolar, asymmetric patterns to the cell poles and with the GAP activity dominating at the lagging cell pole and the GEF activity dominating at the leading cell pole $(46,49-51)$. Importantly, the MgIB GAP activity at the lagging pole blocks MgIA-GTP accumulation at this pole and therefore ensures that T4P only assemble at the leading pole (48). Similarly, because MglA-GTP is incorporated into the Agl/Glt complexes, these complexes disassemble as their reach the lagging pole (36).

Consequently, cells lacking MgIB undergo frequent so-called pseudo-reversals because they have T4P at both poles and do not disassemble the Agl/Glt complexes at the lagging pole $(36,48)$. M. xanthus cells also undergo reversals in a regulated manner stimulated by the Frz chemosensory system (52). The two output response regulators of this system, FrzX (53) and FrzZ $(54,55)$, induce the relocalization of MglA, MgIB, RomR and RomX between the two poles $(46,49-51)$, thus laying the foundation for T4P formation and Agl/Glt complex assembly at the new leading cell pole after a reversal.

c-di-GMP accumulates during growth of $M$. xanthus and at a 10-fold higher level during development $(56,57)$. During growth, c-di-GMP regulates T4P-dependent motility by regulating transcription of the pilA gene, which encodes the major pilin subunit of T4P, and EPS synthesis $(7,56)$. During development, the increased c-di-GMP level induces an increase in EPS synthesis that is essential for fruiting body formation and sporulation (57). Among the 17 GGDEF domain containing proteins encoded by the M. xanthus genome, only DmxA and DmxB have been experimentally shown to have DGC activity $(56,57)$. Lack of DmxA only causes defects during growth and is important for T4P-dependent motility (56). The c-di-GMP receptors involved in regulating pilA transcription and EPS synthesis during growth are not known. Lack of DmxB only causes defects during development, and DmxB is responsible for the increase in the c-di-GMP level during development (57). c-di-GMP binds to the transcriptional regulator Epsl/Nla24 (57), which is an enhancer binding protein important for expression of genes encoding proteins for EPS synthesis (58). It was suggested that c-di-GMP may bind to Epsl/Nla24 during development to stimulate EPS 
126 synthesis (57). However, generally, it is largely unknown how effects of changing c-di-GMP

127 levels are implemented to affect motility and development.

128 Here, we aimed to further understand the molecular basis of how the effects of changing

129 levels of c-di-GMP are implemented in M. xanthus. Because PilZ-domain proteins in several

130 species have been shown to be involved in regulation of flagella-based motility $(14,59-63)$,

131 T4P-dependent motility $(64,65)$, and synthesis of secreted polysaccharides $(12,66,67)$, we

132 addressed the function of PilZ-domain proteins in $M$. xanthus. Previously, bioinformatics

133 analyses identified 24 PilZ-domain proteins in $M$. xanthus (9), among which only three have

134 been analyzed in some details experimentally (see below). Here, we report the identification

135 of two PilZ-domain proteins, renamed to PixA (MXAN_1087/MXAN_RS05220 (old/new

136 annotation)) and PixB (MXAN_2604/MXAN_RS12590), that bind c-di-GMP in vitro. PixB is

137 composed of two PilZ domains and an acetyltransferase domain. PixB functions upstream of

138 the Frz system to regulate reversals and is also important for development. The

139 acetyltransferase activity is essential for activity and, likely stimulated by c-di-GMP binding to

140 the PilZ domains during development. PixA is also important for a correct reversal frequency;

141 however, PixA acts downstream of the Frz system to regulate the polarity of the motility

142 systems and lack of PixA causes pseudo-reversals. 


\section{Results}

145 Phenotypic characterization of mutants lacking individual PilZ domain proteins

146 The $\sim 110$ amino acid PilZ domain is widely distributed in bacteria and can be found either as

147 a stand-alone domain in PilZ single domain proteins or in combination with other domains

148 (9). Genome analyses previously revealed that the $M$. xanthus genome encodes 24 proteins

149 with a PilZ-domain (9) (Fig. 1; S1). 14 are composed only of a PilZ domain while the

150 remaining contain additional domains. Some of the latter are typically involved in signal

151 transduction while four proteins contain a DnaK or DnaJ domain suggesting that they might

152 be involved in protein folding and/or quality control. In fully sequenced Myxococcales

153 genomes, the 24 PilZ-domain proteins are largely conserved in closely related fruiting

154 Cystobacterineae but not in the non-fruiting Cystobacterineae and the more distantly related

155 fruiting Nannocystineae and Sorangineae (Fig. S2A).

156 Among the 24 PilZ domain proteins, three have been previously characterized

157 experimentally. Pkn1 is a Ser/Thr kinase that is important for development (68) (Fig. 1).

158 Based on sequence analysis, the PilZ domain of Pkn1 is predicted not to bind c-di-GMP;

159 however, c-di-GMP binding by Pkn1 has not been studied. PIpA is a single domain PilZ

160 domain protein (Fig. 1), which is important for regulation of the reversal frequency, but not for

161 development (69). Despite possessing the conserved residues in its PilZ domain for c-di-

162 GMP binding (Fig. 1), PlpA was reported not to bind c-di-GMP in vitro and substitutions of

163 amino acids predicted to be important for c-di-GMP binding did not cause reversal defects in

164 vivo (69). MXAN_2902 is an enhancer binding protein (Fig. 1), which is important for fruiting

165 body morphology under a subset of starvation conditions (70) and contains a PilZ domain

166 that is predicted not to bind c-di-GMP; however, c-di-GMP binding has not been studied.

167 We systematically generated in-frame deletion mutations in all 24 genes encoding PilZ

168 domain proteins and tested the strains for motility, EPS accumulation (Fig. 2) and

169 development (Fig. 3). On 0.5\% agar, which is favorable for T4P-dependent motility, the wild-

170 type (WT) strain DK1622 formed the long flares characteristic of T4P-dependent motility

171 while the $\triangle$ pilA mutant, which lacks the major pilin of T4P, did not (Fig. 2). Among the 24

172 mutants generated, the $\triangle p / p A, \triangle M X A N \_1087$ and $\triangle M X A N \_2604$ had a defect in T4P_

173 dependent motility with the formation of shorter flares and significantly reduced colony

174 expansion. Because EPS is important for T4P-dependent motility and its synthesis is

175 regulated by c-di-GMP, we determined EPS synthesis using a Trypan Blue-based

176 colorimetric assay, and observed that all 24 mutants synthesized EPS as WT while the level

177 was decreased in the $\triangle$ pilA mutant, which served as a negative control (71) (Fig. 2). On

$1781.5 \%$ agar, which is favorable to gliding motility, WT displayed the single cell movement at

179 the edge of the colony, whereas the $\triangle a g / Q$ mutant, which lacks the motor of the gliding 
180 motility complex (72, 73), did not (Fig. 2). Among the 24 mutants generated, the $\Delta p / p A$, $\triangle M X A N \_1087$ and $\triangle M X A N \_2604$ mutants had a defect in gliding with fewer single cells at the colony edge and significantly reduced colony expansion. These observations are in agreement with previous analyses of a plpA mutant (69).

We tested the ability of the 24 generated mutants to undergo development with fruiting body formation and sporulation by starving cells under to different condition, i.e. on TPM agar and on a polystyrene surface under submerged conditions. Under both conditions, WT cells had formed fruiting bodies at $24 \mathrm{~h}$ and spores at $120 \mathrm{~h}$ as measured for cells starved under submerged conditions, while the $\triangle m r p C$ mutant, which lacks a transcription factor important for development and served as a negative control (74), had not (Fig. 3). Among the 24 mutants generated, only the $\Delta p k n 1$ and $\triangle M X A N \_2604$ mutants had developmental defects. In agreement with previous observations (68), the $\Delta p k n 1$ mutant formed fruiting bodies but was reduced in sporulation; the $\triangle M X A N \_2604$ mutant did not form fruiting bodies under any of the two conditions tested and was also reduced in sporulation. We did not observe developmental defects in the $\triangle M X A N \_2902$ mutant under the two conditions tested (Fig. 3).

We conclude that the $\triangle p l p A, \triangle M X A N \_1087$ and $\triangle M X A N \_2604$ mutations cause defects in both motility systems and the $\triangle p k n 1$ and $\triangle M X A N \_2604$ mutations cause defects in development. From here on, we focused on MXAN_1087 and MXAN_2604 that we renamed PixA (MXAN_1087/MXAN_RS05220 (old/new annotation)) and PixB (MXAN_2604/MXAN_RS12590/) for PilZ-domain protein in M. $\underline{x}$ anthus $\underline{A}$ and $\underline{B}$.

PixA and PixB have distinct functions in regulation of motility

PixA is a response regulator of two-component systems with an $\mathrm{N}$-terminal PilZ domain that possesses all necessary residues for c-di-GMP binding (Fig. 1; Fig. S1) and a C-terminal receiver domain in which the conserved residues important for phosphorylation including the potentially phosphorylatable Asp180 residue are conserved (Fig. S3) (75). PixB consists of two PilZ domains that both contain the conserved RxxxR motif for c-di-GMP binding but lack the conserved Ser residue in the second motif (Fig. 1; Fig. S1), and an acetyltransferase

207 (AT) domain of the Gcn5-related N-acetyltransferase (GNAT) family. Both proteins as well as 208 the genetic neighborhood of the respective genes are conserved in closely related fruiting Cystobacterineae (Fig. S2A-C).

210 The distance between pixA and the downstream gene supports that pixA is not part of an 211 operon while a similar analysis of the pixB locus supports that pix $B$ could be in an operon 212 with the two downstream genes (Fig. S2BC). To determine whether pix $A$ and pix $B$ are indeed 213 important for motility and development in the case of pix $B$, we ectopically expressed the full214 length genes under the control of their native promoter $\left(P_{\text {nat }}\right)$ from the attB site in the $\Delta$ pix $A$ 
215 and $\triangle$ pixB mutants (Fig. S2BC). Motility assays on $0.5 \%$ and $1.5 \%$ agar plates revealed that

216 the motility defects of both mutants were fully corrected in the two complementation strains

217 (Fig. 4A); similarly, the developmental defects of the $\triangle$ pixB mutant were complemented by

218 ectopic expression of pixB (Fig. 4B). Because the increased c-di-GMP level during

219 development is important for EPS synthesis (57), we determined EPS accumulation in

220 developing cells. We observed that the $\triangle$ pixB mutant accumulated EPS similarly to WT as

221 estimated by the Trypan Blue binding assay (Fig. 4B).

222 Motility defects scored in a population-based assay can be caused by bona fide motility

223 defects or an altered reversal frequency. To discriminate between these defects, we scored

224 the speed and reversal frequency of single cells moving preferentially by T4P-dependent

225 motility in 1\% methylcellulose and by gliding on 1.5\% agar in single cell motility assays.

$226 \triangle$ pixA and $\triangle$ pixB cells moved with the same speed as WT cells under both conditions (Fig.

227 4CE) but reversed significantly more frequently than WT under both conditions (Fig. 4DF).

228 To test whether PixA and PixB regulate cellular reversals in a Frz-dependent manner, we

229 deleted frzE, which encodes the FrzE kinase of the Frz system (76), in the $\triangle$ pixA and $\Delta$ pix $B$

230 mutants. The $\triangle$ frzE mutant had a hypo-reversing phenotype under both conditions tested

231 while the $\triangle$ frzE $\triangle$ pixA hyper-reversed and the $\triangle$ frzE $\triangle$ pixB mutant, similarly to the $\Delta$ frzE

232 mutant, hypo-reversed (Fig. 4DF). These observations suggest that PixA acts downstream of

233 the Frz system to inhibit reversals while PixB acts upstream of the Frz system to inhibit

234 reversals.

235 Lack of PIpA also causes cells to hyper-reverse and PIpA has been suggested to act

236 downstream of the Frz system to inhibit reversals (69). We used epistasis experiments to

237 address whether PixA, PixB and PlpA act in the same pathway. We confirmed that the $\Delta p / p A$

238 mutant hyper-reverses; more importantly, all three double mutants had an additive

239 phenotype and reversed more frequently than the three single mutants (Fig. 4DF). Finally,

240 the triple mutant reversed even more frequently than the three double mutants (Fig. 4DF).

241 Altogether, these observations demonstrate that PixA and PixB, similarly to PlpA, are not

242 important for motility per se but for cells to move with the correct reversal frequency.

243 Moreover, the epistasis tests support that these three proteins act in independent pathways

244 to establish the correct reversal frequency, and with PixB acting upstream of the Frz system

245 to inhibit reversals while PixA and PIpA act downstream of the Frz system to inhibit reversals.

246 PixA is important for unipolar localization of MglA

247 Reversals are induced by Frz signaling while pseudo-reversals, which occur independently of

248 the Frz system, are caused by interfering with the correct localization of the four proteins of

249 the polarity module. In particular, mutations that cause bipolar localization of MgIA also 
250

251

252

253

254

255

256

257

258

259

260

261

262

263

264

265

266

267

268

269

270

271

272

273

274

275

276

277

278

279

280

281

282

283

284

cause hyper-reversals $(46,49,77)$. Because lack of PixA causes hyper-reversals independently of the Frz system (Fig. 4DF), i.e. lack of PixA causes pseudo-reversals, we hypothesized that PixA would be important for correct MgIA localization. To this end, we expressed an MglA-mVenus fusion protein from the native site in WT and the $\triangle$ pixA mutant. Epi-fluorescence microscopy demonstrated that MglA-mVenus in the absence of PixA localizes in a more symmetric bipolar pattern than in WT while the total polar signal remained unchanged (Fig. 5). Lack of PlpA also causes a shift in MgIA-GTP localization towards symmetric bipolar (69).

Altogether, these observations together with the epistasis analyzes demonstrate that PixA and PIpA act in independent pathways to set up the correct localization pattern of the proteins of the polarity module and, in particular, to establish a unipolar localization of MglA.

PixA and PixB bind c-di-GMP in vitro

The PilZ domain in PixA contains the two motifs important for c-di-GMP binding while both PilZ domains in PixB have a substitution in the most C-terminal of the two motifs (Fig. 1; Fig. S1). To determine whether PixA and PixB are can bind c-di-GMP, we performed a differential radial capillary action of ligand assay (DRaCALA) using purified full-length PixA-His 6 and PixB-His 6 (Fig. 6AB; Fig. S4). PixA-His 6 and PixB-His 6 specifically bound ${ }^{32} \mathrm{P}$-labeled c-diGMP (Fig. 6AB). As expected, the PixA ${ }^{\mathrm{R9A}}-\mathrm{His}_{6}$ variant, which contains the Arg9 to Ala substitution in the N-terminal part of the bipartite c-di-GMP binding motif (Fig. 6A; Fig. S4), did not detectably bind ${ }^{32} \mathrm{P}-\mathrm{C}-\mathrm{di}-\mathrm{GMP}$ (Fig. 6A). To determine which of the PilZ domains in PixB are involved in c-di-GMP binding, we overexpressed the PixB ${ }^{\mathrm{R} 121 \mathrm{~A}}-\mathrm{His}_{6}, \mathrm{PixB}^{\mathrm{R} 331 \mathrm{~A}-\mathrm{His}} 6$ and $\mathrm{PixB} \mathrm{B}^{\mathrm{R} 121 \mathrm{~A} / \mathrm{R} 331 \mathrm{~A}}-\mathrm{His}_{6}$ variants, which contain a substitution in the $\mathrm{N}$-terminal part of the Cdi-GMP binding motif (Fig. 6B). However, we were not able to purify any of these variants because they formed inclusion bodies under all conditions tested.

We conclude that PixA binds c-di-GMP in vitro and that the $\mathrm{R}^{9} \mathrm{xxxR}$ motif is important for this binding; PixB also binds c-di-GMP in vitro but it is unclear which domain(s) is involved.

\section{Role of c-di-GMP binding by PixA and PixB in vivo}

To test whether c-di-GMP binding is important for PixA and PixB function in vivo, we ectopically expressed FLAG-tagged full-length WT and mutant variants from the $M \times 8$ attB site in the relevant in-frame deletion mutants (Fig. 7AB). PixA ${ }^{\text {WT }}-$ FLAG and PixA ${ }^{\text {R9A }}-$ FLAG accumulated at similar levels during growth (Fig. 7C) and restored motility including the reversal frequency in the $\triangle$ pixA mutant (Fig. 7A; Fig. S5AB).

PixB $^{\text {WT }}$-FLAG and the variants PixB ${ }^{\text {R121A }}$-FLAG, PixB ${ }^{\text {R331A }}-$ FLAG and PixB ${ }^{\text {R121A/R331A }}$-FLAG accumulated at similar levels during growth and development and all four proteins restored the motility defects of the $\triangle$ pixB mutant (Fig 7AD; Fig. S5AB). While fruiting body formation 
and sporulation was fully restored by PixB ${ }^{W T}-$ FLAG (Fig. 7B), the strain complemented with PixB ${ }^{R 121 A}-F L A G$ displayed delayed fruiting body formation on both solid and submerged condition but restored sporulation at $120 \mathrm{~h}$; however, PixB ${ }^{R 31 \mathrm{~A}}-\mathrm{FLAG}$ and PixB $\mathrm{B}^{\mathrm{R} 121 \mathrm{~A} / \mathrm{R} 331 \mathrm{~A}}$ FLAG neither restored fruiting body formation nor sporulation in the $\triangle$ pixB mutant (Fig. 7B).

These observations support that c-di-GMP binding by PixA and PixB under the conditions tested is not important for their function in motility. By contrast, c-di-GMP binding by the two PilZ domains in PixB appears to be important for fruiting body formation and sporulation, and with the $\mathrm{C}$-terminal domain being the most important.

\section{Structure-function analysis of PixA and PixB}

The receiver domain of PixA contains the conserved residues important for phosphorylation including the putative phosphorylated residue Asp180 (Fig. S3). Substitution of the phosphorylatable Asp to Glu mimics the phosphorylated form in some response regulators $(78,79)$, while the Asp to Asn substitution blocks phosphorylation. Therefore, to test whether phosphorylation of the receiver domain could be important for PixA function, we ectopically expressed FLAG-tagged full-length PixA variants with a D180E or D180N substitution. Only

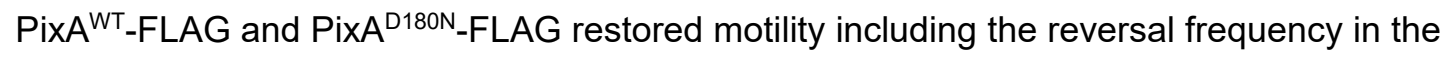
$\triangle$ pixA mutant while PixA ${ }^{\mathrm{D}^{180} \mathrm{E}_{-}}$-FLAG did not (Fig. 8A; Fig. S5CD). PixA ${ }^{\mathrm{WT}}-$ FLAG, PixA ${ }^{\mathrm{D}^{180}} \mathrm{E}_{-}$ FLAG and PixA ${ }^{D 180 N_{-}}$FLAG accumulated at similar levels during growth (Fig. 8B). Altogether, these findings support a scenario whereby PixA might be phosphorylated and in which the non-phosphorylated form of PixA would represents the active form of the protein.

To test which domains in PixB are important for function, we ectopically expressed PixB ${ }^{W T}$ FLAG as well as truncated variants that lacked either the $A T$ domain (PixB ${ }^{\triangle A T}-F L A G$ ) or the two PilZ domains (PixB ${ }^{\triangle P i Z x 2}-F L A G$ ) in the $\triangle p i x B$ mutant. Because the two truncated variants could not be detected by Western blot when expressed from the native pixB promoter, all variants were expressed from the stronger pilA promoter. The two variants as well as the WT protein accumulated at a higher level than PixB ${ }^{W T}$-FLAG expressed from the native promoter during growth and development (Fig. 8C). Importantly, overexpression of PixB ${ }^{W T}$-FLAG restored both motility and development, while overexpression of $\mathrm{PixB}^{\triangle A T}$-FLAG restored neither motility nor development (Fig. 8A, D; Fig. S5C, D). Notably, PixB ${ }^{\triangle P i l Z x 2}-F L A G$ was sufficient to restore motility, but not development (Fig. 8A, D; Fig. S5C, D). Altogether, these observations support that the AT activity is key to PixB function and that c-di-GMP binding to the PilZ domains is important for activating AT activity during development. 


\section{Discussion}

319 Here, we report the identification of two PilZ-domain proteins, PixA and PixB, that are

320 important for regulation of motility in $M$. xanthus and, specifically, important for maintaining a

321 correct cellular reversal frequency during growth. Moreover, PixB is important for completion

322 of the developmental program that results in the formation of spore-filled fruiting bodies.

323 Similarly to the previously identified PilZ-domain protein PIpA (69), PixA and PixB are not

324 important for motility per se but rather are important for regulation of the cellular reversal

325 frequency. Lack of any of the three proteins cause an increase in the reversal frequency

326 suggesting that they all function to inhibit reversals. Importantly, epistasis experiments

327 demonstrated that they act in independent pathways to establish the correct reversal

328 frequency. Moreover, while PixB acts upstream of Frz system, PixA and PlpA act

329 downstream of the Frz system to inhibit reversals.

330 PixB contains two PilZ domain proteins as well as a C-terminal AT domain. PixB binds c-di-

331 GMP in vitro; however, it is not clear which PilZ domain(s) is involved in this binding. By

332 analyzing truncated variants of PixB or variants with single amino acid substitutions in the

333 sequence motifs for c-di-GMP binding, we found that the AT domain was necessary and

334 sufficient for correct reversals during growth. By contrast, the two PilZ domains alone did not

335 complement the reversal defect in the $\triangle$ pixB mutant. Along the same lines, substitutions in

336 the c-di-GMP binding motifs did not interfere with PixB activity in regulation of the reversal

337 frequency under the conditions tested. These observations support a model whereby the AT

338 activity is key to the effect of PixB on Frz-induced reversals during growth while the two PilZ

339 domains and c-di-GMP binding are not important. How then would the AT domain act to

340 inhibit reversals? Acetyltransferases of the GNAT family can acetylate amino groups of

341 different substrates including small molecules, peptidoglycan, nucleotide-linked

342 monosaccharides and proteins; however, the substrate cannot be determined based on

343 protein sequence $(80,81)$. Therefore, further studies are required to determine the substrate

344 of PixB.

345 While the AT domain of PixB was sufficient for correct reversals during growth, all three

346 domains of PixB were important for completion of development. Similarly, PixB variants with

347 single amino acid substitutions in two motifs for c-di-GMP binding did not support

348 development, strongly suggesting that c-di-GMP binding by PixB plays role in fruiting body

349 formation. We previously showed that the level of c-di-GMP increases approximately 10 -fold

350 during development (57). We speculate that the increased c-di-GMP level allows binding of

351 c-di-GMP to the two PilZ domains and boost AT activity of PixB during development. Such a

352 mechanism would be similar to that recently described for an AT from Mycobacterium

353 tuberculosis that depends on cAMP binding to a cyclic nucleotide binding domain to activate 
354

355

356

357

358

359

360

361

362

363

364

365

366

367

368

369

370

371

372

373

374

375

376

377

378

379

380

381

382

383

384

385

386

387

388

389

390

acetyltransferase activity (82). Interestingly, the cellular reversal frequency of WT cells decreases during development (83), thus, it is interesting to speculate that PixB activity is essential for this decrease. In future experiments, it will be of interest to determine the substrate of PixB and to elucidate how the two PilZ domains may regulate PixB activity. Of note, the primary defect in $d m \times B$ mutants, which lack the DGC responsible for the $\sim 10$-fold increase in c-di-GMP during development, is reduced EPS synthesis (57). The $\triangle$ pixB mutant accumulates EPS during development at WT levels arguing that the output of DmxB activity is not only channeled through PixB.

PixA and PlpA both act downstream of the Frz system to inhibit reversals and mutants lacking any of the two proteins still accumulate EPS. These observations argue that PixA and PIpA are not involved in the known responses to altered c-di-GMP levels during growth, i.e. altered EPS synthesis and reduced pilA transcription. PixA is a response regulator that binds c-di-GMP in vitro. Under the conditions tested, c-di-GMP by the PilZ domain was not important for regulation of motility. Moreover, genetic evidence supports that the receiver domain could be phosphorylated and that the non-phosphorylated form represents the active form of the protein. PIpA is a stand-alone PilZ domain protein, which was reported not to bind c-di-GMP in vitro, and substitutions in the c-di-GMP binding sequence motifs did not interfere with PIpA activity in vivo (69). The Frz-independent pseudo-reversals resulting from lack of PixA and PIpA are characteristic of mutants in which the localization of the small GTPase MgIA, the key regulator of motility in M. xanthus, in its GTP-bound form is shifted from unipolar to bipolar $(46,49,77,84,85)$. Consistently, in $\Delta p / p A(69)$ and $\triangle p i x A$ mutants, MglA localization is shifted to bipolar. These observations together with the epistasis experiments strongly argue that PixA and PIpA act in independent pathways at the level of the cell polarity system that establish unipolar T4P and Agl/GIt complex assembly at the leading cell pole; and, in the case of the Agl/Glt complexes, their disassembly at the lagging pole. At the leading cell pole, MgIA-GTP stimulates T4P formation and assembly of the Agl/GIt complexes $(36,47,48)$ while the MgIA GAP MglB at the lagging pole inhibits MgIA-GTP accumulation at this pole and, therefore, T4P formation and Agl/Glt complex disassembly $(36,48)$. Thus, for both motility systems, MgIB with its GAP activity at the lagging pole is essential for persistent directional motion without Frz-independent pseudo-reversals. PIpA was reported to localize to the lagging cell pole in an MglB-dependent manner (69) while it is not known whether PixA is polarly localized. In future experiments, it will be interesting to test for interactions between PIpA, PixA and proteins of the polarity module. Genetic evidence suggest that PixA activity could be regulated by phosphorylation of the receiver domain. Typically, partner proteins of two component systems are encoded by neighboring genes (75); however, in $M$. xanthus, these proteins are are often encoded by orphan genes (86). This is also the case for the pix $A$ gene, where there is no neighboring gene encoding a 
bioRxiv preprint doi: https://doi org/10.1101/2021.03.04.433885; this version posted March 4, 2021. The copyright holder for this preprint (which was not certified by peer review) is the author/funder, who has granted bioRxiv a license to display the preprint in perpetuity. It is made available under aCC-BY-NC 4.0 International license.

391 histidine protein kinase. Therefore, it will also be of interest to identify the potential partner

392 kinase of PixA.

393 Interestingly, Pseudomonas aeruginosa as well as Xanthomonas axonopodis pv. citri contain

394 a stand-alone PilZ protein that stimulates T4P formation $(64,65)$. By contrast, in M. xanthus,

395 PIpA, PixA and PixB regulate T4P-dependent motility rather than T4P formation. We

396 conclude that PilZ domain proteins can act at different levels to affect T4P-dependent

397 motility.

398 


\section{Acknowledgement}

400 The authors thank Magdalena Anna Świątek-Połatyńska for constructing SA6462. This work

401 was supported by Deutsche Forschungsgemeinschaft (DFG, German Research Council)

402 within the framework of the SFB987 "Microbial Diversity in Environmental Signal Response"

403 and the SPP1879 "Nucleotide second messenger signaling in bacteria" as well as by the Max

404 Planck Society. The funders had no role in study design, data collection and interpretation.

\section{Conflict of Interest}

406 The authors declare no conflict of interest.

\section{Data Availability}

408 All the data that support the findings of this study are all included in the manuscript.

409 Author contributions

410 S.K., D.Sk., D.Sc. and L.S.-A. conceptualized the study.

411 D.Sk., S.K., D.Sc., P.K. and M.P.B. performed bioinformatics studies.

412 S.K., D.Sk., E.S., P.K. and M.P.B. performed genetic and molecular microbiology

413 experiments.

414 S.K., D.Sz. and P.K. performed microscopy studies.

415 D.Sk, D.Sz. and S.K. performed biochemistry experiments.

416 S.K., D.S. and L.S.-A. wrote the original draft of the manuscript.

417 All authors reviewed and edited the original manuscript.

418 L.S.-A. acquired funding and provided supervision. 
420

421

422

423

424

425

426

427

428

429

430

431

432

433

434

435

436

437

438

439

440

441

442

443

444

445

446

447

448

449

450

451

452

453

454

455

\section{Materials and methods}

Cultivation of $M$. xanthus and $E$. coli. All $M$. xanthus strains used in this study are derivatives of WT DK1622 (87). In-frame deletions were generated as described (86). All M. xanthus strains generated were verified by PCR. M. xanthus strains, plasmids and oligonucleotides used are listed in Table 1, Table 2, and Table S1, respectively. $M$. xanthus cells were grown at $32{ }^{\circ} \mathrm{C}$ in $1 \% \mathrm{CTT}$ medium or on $1 \% \mathrm{CTT} / 1.5 \%$ agar plates at $32{ }^{\circ} \mathrm{C}$ with addition of kanamycin $\left(40 \mu \mathrm{g} \mathrm{ml}^{-1}\right)$ or oxytetracycline $\left(10 \mu \mathrm{g} \mathrm{ml}^{-1}\right)(88)$. E. coli cells were cultivated in LB (89) liquid media with shaking or on LB $1.5 \%$ agar plates at $37^{\circ} \mathrm{C}$ with addition of kanamycin $\left(40 \mu \mathrm{g} \mathrm{ml}^{-1}\right)$ or tetracycline $\left(10 \mu \mathrm{g} \mathrm{ml}^{-1}\right)$. All plasmids were propagated in E. coli Top10 (Invitrogen ${ }^{\mathrm{TM}}$ life technologies) unless otherwise mentioned.

Motility assays. Motility assay were done as described with modifications (34). Briefly, exponentially growing $M$. xanthus cells were harvested at $5000 \times g$ for $5 \mathrm{~min}$ and resuspended in $1 \%$ CTT to $7 \times 10^{9}$ cells $\mathrm{ml}^{-1}$. From this suspension $5 \mu$ were spotted on $0.5 \%$ agar with addition of $1 \%$ CTT to final concentration $0.5 \%$ for T4P-dependent motility and on $1.5 \%$ agar with addition of $1 \%$ CTT to final concentration $0.5 \%$ for gliding motility. Cells were incubated in dark at $32^{\circ} \mathrm{C}$ for $24 \mathrm{~h}$. Colony morphology was imaged using a Leica M205FA Stereomicroscope with a Hamamatsu ORCA-flash V2 Digital CMOS camera and a Leica DMi8 inverted microscope with a Leica DFC280 camera.

Development. M. xanthus development assays were performed as described (90) on solid TPM (10 mM Tris-HCl pH 7.6, 1 mM K $\left.\mathrm{HPO}_{4} / \mathrm{KH}_{2} \mathrm{PO}_{4} \mathrm{pH} 7.6,8 \mathrm{mM} \mathrm{MgSO}\right)_{4}$ ) 1.5\% agar plates and under MC7 buffer (10 mM MOPS pH 6.8, $1 \mathrm{mM} \mathrm{CaCl}_{2}$ ). Briefly, exponentially growing cells were harvested at 5,000 $\times \mathrm{g}$ for 5 min and resuspended in MC7 buffer to $7 \times$ $10^{9}$ cells $\mathrm{ml}^{-1} .20 \mu \mathrm{l}$ of cell suspension was spotted on TPM agar and $50 \mu \mathrm{l}$ was added to 350 $\mu \mathrm{l}$ of MC7 buffer in 24-well polystyrene plate (Falcon). At $24 \mathrm{~h}$ and $120 \mathrm{~h}$ fruiting bodies were imaged with a Leica M205FA stereomicroscope with a Hamamatsu ORCA-flash V2 Digital CMOS camera and a Leica DMi8 inverted microscope with Leica DFC280 camera. To determine sporulation efficiency, cells at $120 \mathrm{~h}$ of development were harvested from one of the 24 -well polystyrene plate (Falcon). Cells were sonicated 1 min (30\% pulse; $50 \%$ amplitude with a UP200St sonifier and microtip, Hielscher) to disperse fruiting bodies and then incubated at $55^{\circ} \mathrm{C}$ for $2 \mathrm{~h}$. Sporulation efficiency was calculated as the number of sonication and heat resistant spores formed after $120 \mathrm{~h}$ of development, relatively to WT. Spores were counted in a counting chamber (Depth $0.02 \mathrm{~mm}$, Hawksley).

Single cell motility assays. Assays were performed as described (50). Briefly, to track individual cells moving by T4P-dependent motility, $5 \mu \mathrm{l}$ of an exponentially growing cell culture was spotted on 24-well polystyrene plate (Falcon) and incubated at room temperature for $10 \mathrm{~min}$. in the dark. Then cells were covered with $500 \mu \mathrm{l}$ of $1 \%$ methylcellulose in MMC 
buffer (10 mM MOPS pH 7.6, $4 \mathrm{mM} \mathrm{MgSO}_{4}, 2 \mathrm{mM} \mathrm{CaCl}_{2}$ ) and incubated in the dark at room temperature for $30 \mathrm{~min}$. Cell movement was recorded for $10 \mathrm{~min}$ at $20 \mathrm{~s}$ intervals. For analysis Metamorph (Molecular Devices) and ImageJ 1.52b (91) were used. For each cell, the distance moved per $20 \mathrm{~s}$ interval was determined and the speed per minute calculated; for reversals, the number of reversals per cell per $10 \mathrm{~min}$ was determined. Only cells that displayed movement were included in these analyses. To track individual cells moving by gliding, $5 \mu \mathrm{l}$ of exponentially growing cultures were placed on $1.5 \%$ agar plates supplemented with $0.5 \% \mathrm{CTT}$, covered by a coverslip and incubated at $32{ }^{\circ} \mathrm{C}$. After $4 \mathrm{~h}$, cells were observed for $10 \mathrm{~min}$ at $20 \mathrm{~s}$ intervals at RT, and speed per minute as well as the number of reversals per 10 min calculated.

Trypan Blue dye binding assay. Assay was performed as described (56)._Briefly, overnight cultures were grown to a density of $7 \times 10^{8}$ cells ml-1 and then were centrifuged at 5,000 $\times \mathrm{g}$

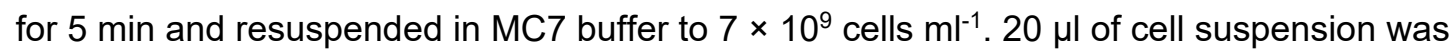
spotted on $0.5 \%$ agar supplemented with $0.5 \%$ CTT or on $1.5 \%$ agar plates supplemented with TPM buffer containing Trypan Blue in final concentration of $10 \mu \mathrm{g} / \mathrm{ml}$. Plates were incubated at $32^{\circ} \mathrm{C}$ in the darkness for $24 \mathrm{~h}$. Colonies were visualized using a plate scanner.

\section{Microscopy and analysis of fluorescence microscopy images. Epifluorescence microscopy} was performed as described (50). Briefly, exponentially growing cells were placed on a thin $1.5 \%$ agar pad buffered with TPM buffer on a glass slide and immediately covered with a coverslip. After 30 min at $32{ }^{\circ} \mathrm{C}$, cells were visualized using a Leica DMi8 inverted microscope and phase contrast and fluorescence images acquired using a Leica DFC280 camera. Cells in phase contrast images were automatically detected using Oufti48. Fluorescence signals in segmented cells were identified and analyzed using a custom-made Matlab v2016b (MathWorks) script as described in (50). The script divides a cell into three regions: polar region 1, polar region 2 and the cytoplasmic region. The polar regions are defined as the parts of a cell within a distance of 10 pixels, corresponding to $0.64 \mu \mathrm{m}$, from a tip of a cell. The cytoplasmic region includes all pixels of the cell with the exception of the polar regions. A polar cluster was identified when three or more connected pixels within a polar region had a fluorescence signal higher than a cell-specific threshold signal of two standard deviations above the average fluorescence signal in the cytoplasmic region. The fluorescence of a polar cluster was defined as the sum of the fluorescence signal of all connected pixels that exceeded the threshold value in that polar region. The cytoplasmic signal was defined as the sum of the fluorescence signal of all pixels excluding the polar clusters. For each cell with polar cluster(s), an asymmetry index ( $\omega)$ was calculated as

$$
\omega=\frac{\text { total fluorescence at pole } 1-\text { total fluorescence at pole } 2}{\text { total fluorescence at pole } 1+\text { total fluorescence at pole } 2}
$$


491 By definition, pole 1 is the pole with the highest fluorescence. $\omega$ varies between 0 (bipolar 492 symmetric localization) and 1 (unipolar localization). The localization patterns were binned 493 from the $\omega$ values as follows: unipolar $(\omega>0.9)$, bipolar asymmetric $(0.9>\omega>0.2)$ and 494 bipolar symmetric $(\omega<0.2)$. Diffuse localization was determined when no polar signal was 495 detected. For time-lapse epifluorescence microscopy, cells were prepared as described and 496 recorded for 15 min with images captured every $30 \mathrm{~s}$. Data were processed with Metamorph $497 \quad 7.5$ and ImageJ 1.52b.

498 Immunoblot analysis. Protein concentration was measured using a Bradford assay (BioRad). 499 Rabbit polyclonal a-PilC (1:5000 dilution) (Bulyha et al., 2009) and a-FLAG (Rockland, 500 1:1500 dilution) antibodies were used together with horseradish-conjugated goat a-rabbit 501 immunoglobulin G (Sigma-Aldrich) as secondary antibody. Immunoblots were performed as 502 described (89). Blots were developed using Luminata crescendo Western HRP Substrate 503 (Millipore) and visualized with a LAS-4000 luminescent image analyzer (Fujifilm).

504 Protein purification. To purify PixA-His 6 , PixA ${ }^{\mathrm{R} 9 \mathrm{~A}}-\mathrm{His}_{6}, \mathrm{PixB}_{-} \mathrm{His}_{6}, \mathrm{PixB}^{\mathrm{R} 121 \mathrm{~A}}-\mathrm{His}_{6}$ and PixB ${ }^{\mathrm{R} 331 \mathrm{~A}}$ $505 \mathrm{His}_{6}, \mathrm{PixB}^{\mathrm{R} 121 \mathrm{~A} / \mathrm{R} 331}-\mathrm{His}_{6}$ and PixB-His 6 , E. coli Rosseta 2 (DE3)/pLysS strain (Novagen) was 506 transformed with pSK51, pSK141, pES09, pPK21, pES13 and pPK22 respectively. Cultures 507 were grown in $1 \mathrm{~L}$ of LB with addition of chloramphenicol and kanamycin at $37^{\circ} \mathrm{C}$ to an $\mathrm{OD}_{600}$ 508 of $0.5-0.7$. Protein expression was induced by addition of Isopropyl $\beta-d-1$ 509 thiogalactopyranoside (IPTG) to a final concentration of $0.5 \mathrm{mM}$ for $3 \mathrm{~h}$ at $37^{\circ} \mathrm{C}$. Cells were 510 harvested by centrifugation at $3,800 \times g$ for $10 \mathrm{~min}$ at $4{ }^{\circ} \mathrm{C}$ and resuspended in lysis buffer 511 (50 mM NaH${ }_{2} \mathrm{PO}_{4}, 300 \mathrm{mM} \mathrm{NaCl}, 50 \mathrm{mM}$ imidazole, $5 \%$ glycerol and Complete Protease 512 Inhibitor Cocktail Tablet (Roche), $\mathrm{pH}$ 8.0). Next, cells were disrupted with French press and 513 centrifuged at $48,000 \times \mathrm{g}, 4^{\circ} \mathrm{C}$ for $40 \mathrm{~min}$. Cleared cell lysate was filter with $0.45 \mu \mathrm{m}$ sterile 514 filter (Millipore Merck, Schwalbach) and loaded onto a 5 ml HiTrap Chelating HP column (GE 515 Healthcare) preloaded with $\mathrm{NiSO}_{4}$ as described by the manufacturer and pre-equilibrated in 516 wash buffer ( $50 \mathrm{mM} \mathrm{NaH}_{2} \mathrm{PO}_{4}, 300 \mathrm{mM} \mathrm{NaCl}, 50 \mathrm{mM}$ imidazole, $5 \%$ glycerol, $\mathrm{pH}$ 8.0). The 517 column was washed with 20 column volumes of column wash buffer. Proteins were eluted 518 with elution buffer $\mathrm{A}\left(50 \mathrm{mM} \mathrm{NaH}_{2} \mathrm{PO}_{4}, 300 \mathrm{mM} \mathrm{NaCl}, 500 \mathrm{mM}\right.$ imidazole, $5 \%$ glycerol, pH 519 8.0) using a linear imidazole gradient from 50 to $500 \mathrm{mM}$. Fractions containing purified $\mathrm{His}_{6}{ }^{-}$ 520 tagged proteins were combined and loaded onto a HiLoad 16/600 Superdex 75 pg (GE 521 Healthcare) gel filtration column that was equilibrated with buffer ( $50 \mathrm{mM} \mathrm{NaH}_{2} \mathrm{PO}_{4}, 300 \mathrm{mM}$ $522 \mathrm{NaCl}, 5 \%$ glycerol, $\mathrm{pH} 6.5)$. Fractions containing $\mathrm{His}_{6}$-tagged proteins were pooled, frozen in 523 liquid nitrogen and stored at $-80^{\circ} \mathrm{C}$.

524 In vitro c-di-GMP binding assay. c-di-GMP binding was determined using a DRaCALA assay 525 with ${ }^{32} \mathrm{P}$-labeled c-di-GMP as described $(92,93) .{ }^{32} \mathrm{P}$-labeled c-di-GMP was prepared by 526 incubating $10 \mu \mathrm{M} \mathrm{His}_{6}$-DgcA with $\left.1 \mathrm{mM} \mathrm{GTP/[ \alpha -}{ }^{32} \mathrm{P}\right]-\mathrm{GTP}\left(0.1 \mu \mathrm{Ci} \mu \mathrm{l}^{-1}\right)$ in reaction buffer 
527 (total volume of $200 \mu \mathrm{l}$ ) overnight at $30^{\circ} \mathrm{C}$. The reaction mixture was then incubated with 5

528 units of Antarctic Phosphatase (NEB) for $1 \mathrm{~h}$ at $22^{\circ} \mathrm{C}$ to hydrolyze unreacted GTP. The

529 reaction was stopped by incubation for $10 \mathrm{~min}$ at $95^{\circ} \mathrm{C}$. The reaction was centrifuged (10

$530 \min$., $20,000 \times \mathrm{g}, 20^{\circ} \mathrm{C}$ ) and the supernatant used for the binding assay. ${ }^{32} \mathrm{P}$-labeled c-di-

531 GMP was mixed with $20 \mu \mathrm{M}$ protein and incubated for $10 \mathrm{~min}$ at RT in binding buffer (10 mM

532 Tris, $\mathrm{pH} 8.0,100 \mathrm{mM} \mathrm{NaCl}, 5 \mathrm{mM} \mathrm{MgCl}_{2}$ ). $15 \mu \mathrm{l}$ of this reaction mixture was transferred to a

533 nitrocellulose filter, allowed to dry and imaged using a STORM 840 Scanner (Amersham

534 Biosciences). For competition experiments, $0.4 \mathrm{mM}$ unlabelled c-di-GMP (BioLog) or GTP

535 (Sigma-Aldrich) was added.

536 Bioinformatic analysis. The KEGG SSDB (Sequence Similarity Database) (94) database was

537 used to identify homologs of the PilZ domain proteins in other fully sequenced Myxococcales

538 genomes using a reciprocal best BlastP hit method. Protein domains were identified using

539 Pfam v33.1 (pfam.xfam.org) (95) and MyHits Motif scan (https://myhits.isb-sib.ch/cgi-

540 bin/motif scan) (96). Multiple Alignment using Fast Fourier Transform from EMBL-EBI (97)

541 was used to align protein sequences. Sequence identity/similarity was calculated using

542 EMBOSS Needle software (98) (pairwise sequence alignment).

543 


\section{References}

545 1. Hengge R. 2020. Linking bacterial growth, survival, and multicellularity - small signaling $546 \quad$ molecules as triggers and drivers. Curr Opin Microbiol 55:57-66.

547 2. Römling U, Galperin MY, Gomelsky M. 2013. Cyclic di-GMP: the first 25 years of a $548 \quad$ universal bacterial second messenger. Microbiol Mol Biol Rev 77:1-52.

549 3. Jenal U, Reinders A, Lori C. 2017. Cyclic di-GMP: second messenger extraordinaire. $550 \quad$ Nat Rev Microbiol 15:271-284.

551

4. Duerig A, Abel S, Folcher M, Nicollier M, Schwede T, Amiot N, Giese B, Jenal U. 2009.

552

553

554

555

556

557

558

559

560

561

562

563

564

565

566

567

568

569

570

571

572

573

574

575

576

577

578

579 Second messenger-mediated spatiotemporal control of protein degradation regulates bacterial cell cycle progression. Genes Dev 23:93-104.

5. Qi Y, Chuah MLC, Dong X, Xie K, Luo Z, Tang K, Liang Z-X. 2011. Binding of cyclic diguanylate in the non-catalytic EAL domain of FimX induces a long-range conformational change. J Biol Chem 286:2910-2917.

6. Newell PD, Monds RD, O'Toole GA. 2009. LapD is a bis-( $\left.3^{\prime}, 5^{\prime}\right)$-cyclic dimeric GMPbinding protein that regulates surface attachment by Pseudomonas fluorescens Pf0-1. Proc Natl Acad Sci USA 106:3461-3466.

7. Petters T, Zhang X, Nesper J, Treuner-Lange A, Gómez-Santos N, Hoppert M, Jenal U, Søgaard-Andersen L. 2012. The orphan histidine protein kinase SgmT is a c-diGMP receptor and regulates composition of the extracellular matrix together with the orphan DNA binding response regulator DigR in Myxococcus xanthus. Mol Microbiol 84:147-165.

8. Navarro MVAS, De N, Bae N, Wang Q, Sondermann H. 2009. Structural analysis of the GGDEF-EAL domain-containing c-di-GMP receptor FimX. Structure 17:1104-1116.

9. Amikam D, Galperin MY. 2006. PilZ domain is part of the bacterial c-di-GMP binding protein. Bioinformatics 22:3-6.

10. Christen M, Christen B, Allan MG, Folcher M, Jeno P, Grzesiek S, Jenal U. 2007. DgrA is a member of a new family of cyclic diguanosine monophosphate receptors and controls flagellar motor function in Caulobacter crescentus. Proc Natl Acad Sci U S A 104:4112-7.

11. Ramelot TA, Yee A, Cort JR, Semesi A, Arrowsmith CH, Kennedy MA. 2007. NMR structure and binding studies confirm that PA4608 from Pseudomonas aeruginosa is a PilZ domain and a c-di-GMP binding protein. Proteins: Structure, Function, and Bioinformatics 66:266-271.

12. Merighi M, Lee VT, Hyodo M, Hayakawa Y, Lory S. 2007. The second messenger bis(3'-5')-cyclic-GMP and its PilZ domain-containing receptor Alg44 are required for alginate biosynthesis in Pseudomonas aeruginosa. Mol Microbiol 65:876-95. 
580 13. Wilksch JJ, Yang J, Clements A, Gabbe JL, Short KR, Cao H, Cavaliere R, James CE,

581

582

583

584

585

586

587

588

589

590

591

592

593

594

595

596

597

598

599

600

601

602

603

604

605

606

607

608

609

610

611

612

613

614

615

Whitchurch CB, Schembri MA, Chuah MLC, Liang Z-X, Wijburg OL, Jenney AW, Lithgow T, Strugnell RA. 2011. MrkH, a novel c-di-GMP-dependent transcriptional activator, controls Klebsiella pneumoniae biofilm formation by regulating type 3 fimbriae expression. PLoS Pathog 7:e1002204.

14. Ryjenkov DA, Simm R, Römling U, Gomelsky M. 2006. The PilZ domain is a receptor for the second messenger c-di-GMP: the PilZ domain protein YcgR controls motility in enterobacteria. J Biol Chem 281:30310-4.

15. Pratt JT, Tamayo R, Tischler AD, Camilli A. 2007. PilZ domain proteins bind cyclic diguanylate and regulate diverse processes in Vibrio cholerae. J Biol Chem 282:1286070.

16. Wang YC, Chin KH, Tu ZL, He J, Jones CJ, Sanchez DZ, Yildiz FH, Galperin MY, Chou $\mathrm{SH}$. 2016. Nucleotide binding by the widespread high-affinity cyclic di-GMP receptor MshEN domain. Nat Commun 7:12481.

17. Roelofs KG, Jones CJ, Helman SR, Shang X, Orr MW, Goodson JR, Galperin MY, Yildiz FH, Lee VT. 2015. Systematic identification of cyclic-di-GMP binding proteins in Vibrio cholerae reveals a novel C'class of cyclic-di-GMP-binding ATPases associated with type II secretion systems. PLoS Pathog 11:e1005232.

18. Li W, He ZG. 2012. LtmA, a novel cyclic di-GMP-responsive activator, broadly regulates the expression of lipid transport and metabolism genes in Mycobacterium smegmatis. Nucleic Acids Res 40:11292-11307.

19. Chin KH, Lee YC, Tu ZL, Chen CH, Tseng YH, Yang JM, Ryan RP, McCarthy Y, Dow JM, Wang AH, Chou SH. 2010. The cAMP receptor-like protein CLP is a novel c-diGMP receptor linking cell-cell signaling to virulence gene expression in Xanthomonas campestris. J Mol Biol 396:646-662.

20. Fazli M, O'Connell A, Nilsson M, Niehaus K, Dow JM, Givskov M, Ryan RP, TolkerNielsen T. 2011. The CRP/FNR family protein Bcam1349 is a c-di-GMP effector that regulates biofilm formation in the respiratory pathogen Burkholderia cenocepacia. Mol Microbiol 82:327-341.

21. Hickman JW, Harwood CS. 2008. Identification of FleQ from Pseudomonas aeruginosa as a c-di-GMP-responsive transcription factor. Mol Microbiol 69:376-389.

22. Srivastava D, Harris RC, Waters CM. 2011. Integration of cyclic di-GMP and quorum sensing in the control of vpsT and aphA in Vibrio cholerae. J Bacteriol 193:6331-6341.

23. Krasteva PV, Fong JC, Shikuma NJ, Beyhan S, Navarro MV, Yildiz FH, Sondermann H. 2010. Vibrio cholerae VpsT regulates matrix production and motility by directly sensing cyclic di-GMP. Science 327:866-8. 
616 24. Tschowri N, Schumacher MA, Schlimpert S, Chinnam NB, Findlay KC, Brennan RG,

617

618

619

620

621

622

623

624

625

626

627

628

629

630

631

632

633

634

635

636

637

638

639

640

641

642

643

644

645

646

647

648

649

650

651

Buttner MJ. 2014. Tetrameric c-di-GMP mediates effective transcription factor dimerization to control Streptomyces development. Cell 158:1136-1147.

25. Skotnicka D, Steinchen W, Szadkowski D, Cadby IT, Lovering AL, Bange G, SøgaardAndersen L. 2020. CdbA is a DNA-binding protein and c-di-GMP receptor important for nucleoid organization and segregation in Myxococcus xanthus. Nat Commun 11:1791.

26. Schäper S, Steinchen W, Krol E, Altegoer F, Skotnicka D, Søgaard-Andersen L, Bange G, Becker A. 2017. AraC-like transcriptional activator CuxR binds c-di-GMP by a PilZlike mechanism to regulate extracellular polysaccharide production. Proc Natl Acad Sci USA 114:E4822-E4831.

27. Trampari E, Stevenson CE, Little RH, Wilhelm T, Lawson DM, Malone JG. 2015. Bacterial rotary export ATPases are allosterically rregulated by the nucleotide second messenger cyclic-di-GMP. J Biol Chem 290:24470-83.

28. Galperin MY. 2004. Bacterial signal transduction network in a genomic perspective. Environ Microbiol 6:552-67.

29. Konovalova A, Petters T, Søgaard-Andersen L. 2010. Extracellular biology of Myxococcus xanthus. FEMS Microbiol Rev 34:89-106.

30. Muñoz-Dorado J, Marcos-Torres FJ, Garcia-Bravo E, Moraleda-Munoz A, Perez J. 2016. Myxobacteria: moving, killing, feeding, and surviving together. Front Microbiol $7: 781$.

31. Mercier R, Mignot T. 2016. Regulations governing the multicellular lifestyle of Myxococcus xanthus. Current Opinion in Microbiology 34:104-110.

32. Schumacher D, Søgaard-Andersen L. 2017. Regulation of cell polarity in motility and cell division in Myxococcus xanthus. Annu Rev Microbiol 71:61-78.

33. Pérez-Burgos M, Søgaard-Andersen L. 2020. Regulation by Cyclic di-GMP in Myxococcus xanthus. In Chou S-H, Guiliani N, Lee VT, Römling U (ed), Microbial Cyclic Di-Nucleotide Signaling. Springer Nature,

34. Shi W, Zusman DR. 1993. The two motility systems of Myxococcus xanthus show different selective advantages on various surfaces. Proc Natl Acad Sci U S A 90:337882.

35. Hodgkin J, Kaiser D. 1979. Genetics of gliding motility in Myxococcus-xanthus (Myxobacterales) - 2 gene systems control movement. Mol Gen Genet 171:177-191.

36. Treuner-Lange A, Macia E, Guzzo M, Hot E, Faure LM, Jakobczak B, Espinosa L, Alcor D, Ducret A, Keilberg D, Castaing JP, Lacas Gervais S, Franco M, Søgaard-Andersen L, Mignot T. 2015. The small G-protein MgIA connects to the MreB actin cytoskeleton at bacterial focal adhesions. J Cell Biol 210:243-56. 
652 37. Mignot T, Shaevitz JW, Hartzell PL, Zusman DR. 2007. Evidence that focal adhesion

653

654

655

656

657

658

659

660

661

662

663

664

665

666

667

668

669

670

671

672

673

674

675

676

677

678

679

680

681

682

683

684

685

686 complexes power bacterial gliding motility. Science 315:853-6.

38. Skerker JM, Berg HC. 2001. Direct observation of extension and retraction of type IV pili. Proc Natl Acad Sci U S A 98:6901-4.

39. Maier B, Potter L, So M, Long CD, Seifert HS, Sheetz MP. 2002. Single pilus motor forces exceed 100 pN. Proc Natl Acad Sci USA 99:16012-16017.

40. Sun H, Zusman DR, Shi W. 2000. Type IV pilus of Myxococcus xanthus is a motility apparatus controlled by the frz chemosensory system. Curr Biol 10:1143-1146.

41. Pérez-Burgos M, Garcia-Romero I, Jung J, Schander E, Valvano MA, SøgaardAndersen L. 2020. Characterization of the exopolysaccharide biosynthesis pathway in Myxococcus xanthus. J Bacteriol 202:e00335-20.

42. Li Y, Sun H, Ma X, Lu A, Lux R, Zusman D, Shi W. 2003. Extracellular polysaccharides mediate pilus retraction during social motility of Myxococcus xanthus. Proc Natl Acad Sci USA 100:5443-5448.

43. Lu A, Cho K, Black WP, Duan X-Y, Lux R, Yang Z, Kaplan HB, Zusman DR, Shi W. 2005. Exopolysaccharide biosynthesis genes required for social motility in Myxococcus xanthus. Mol Microbiol 55:206-220.

44. Yang Z, Ma X, Tong L, Kaplan HB, Shimkets LJ, Shi W. 2000. Myxococcus xanthus dif genes are required for biogenesis of cell surface fibrils essential for social gliding motility. J Bacteriol 182:5793-5798.

45. Islam ST, Vergara Alvarez I, Saïdi F, Guiseppi A, Vinogradov E, Sharma G, Espinosa L, Morrone C, Brasseur G, Guillemot J-F, Benarouche A, Bridot J-L, Ravicoularamin G, Cagna A, Gauthier C, Singer M, Fierobe H-P, Mignot T, Mauriello EMF. 2020. Modulation of bacterial multicellularity via spatio-specific polysaccharide secretion. PLOS Biology 18:e3000728.

46. Leonardy S, Miertzschke M, Bulyha I, Sperling E, Wittinghofer A, Søgaard-Andersen L. 2010. Regulation of dynamic polarity switching in bacteria by a Ras-like G-protein and its cognate GAP. EMBO J 29:2276-89.

47. Mercier R, Bautista S, Delannoy M, Gibert M, Guiseppi A, Herrou J, Mauriello EMF, Mignot T. 2020. The polar Ras-like GTPase MgIA activates type IV pilus via SgmX to enable twitching motility in Myxococcus xanthus. Proc Natl Acad Sci U S A 117:2836628373.

48. Potapova A, Carreira LAM, Søgaard-Andersen L. 2020. The small GTPase MgIA together with the TPR domain protein SgmX stimulates type IV pili formation in $M$. xanthus. Proc Natl Acad Sci U S A 117:23859-23868. 
687

688

689

690

691

692

693

694

695

696

697

698

699

700

701

702

703

704

705

706

707

708

709

710

711

712

713

714

715

716

717

718

719

720

721

49. Zhang Y, Franco M, Ducret A, Mignot T. 2010. A bacterial Ras-like small GTP-binding protein and its cognate GAP establish a dynamic spatial polarity axis to control directed motility. PLoS Biol 8:e1000430.

50. Szadkowski D, Harms A, Carreira LAM, Wigbers M, Potapova A, Wuichet K, Keilberg D, Gerland U, Søgaard-Andersen L. 2019. Spatial control of the GTPase MgIA by localized RomR-RomX GEF and MgIB GAP activities enables Myxococcus xanthus motility. Nat Microbiol 4:1344-1355.

51. Leonardy S, Freymark G, Hebener S, Ellehauge E, Søgaard-Andersen L. 2007. Coupling of protein localization and cell movements by a dynamically localized response regulator in Myxococcus xanthus. EMBO J 26:4433-44.

52. Blackhart BD, Zusman DR. 1985. "Frizzy" genes of Myxococcus xanthus are involved in control of frequency of reversal of gliding motility. Proc Natl Acad Sci USA 82:87718774.

53. Guzzo M, Murray SM, Martineau E, Lhospice S, Baronian G, My L, Zhang Y, Espinosa L, Vincentelli R, Bratton BP, Shaevitz JW, Molle V, Howard M, Mignot T. 2018. A gated relaxation oscillator mediated by FrzX controls morphogenetic movements in Myxococcus xanthus. Nat Microbiol 3:948-959.

54. Inclan YF, Vlamakis HC, Zusman DR. 2007. FrzZ, a dual CheY-like response regulator, functions as an output for the Frz chemosensory pathway of Myxococcus xanthus. Mol Microbiol 65:90-102.

55. Kaimer C, Zusman DR. 2013. Phosphorylation-dependent localization of the response regulator FrzZ signals cell reversals in Myxococcus xanthus. Mol Microbiol 88:740-53.

56. Skotnicka D, Petters, T., Heering J, Hoppert M, Kaever V, Søgaard-Andersen L. 2016. Cyclic di-GMP regulates type IV pilus-dependent motility in Myxococcus xanthus. J Bacteriol 198:77-90.

57. Skotnicka D, Smaldone GT, Petters T, Trampari E, Liang J, Kaever V, Malone JG, Singer M, Søgaard-Andersen L. 2016. A minimal threshold of c-di-GMP is essential for fruiting body formation and sporulation in Myxococcus xanthus. PLoS Genet 12:e1006080.

58. Lancero H, Caberoy NB, Castaneda S, Li YN, Lu A, Dutton D, Duan XY, Kaplan HB, Shi WY, Garza AG. 2004. Characterization of a Myxococcus xanthus mutant that is defective for adventurous motility and social motility. Microbiology 150:4085-4093.

59. Paul K, Nieto V, Carlquist WC, Blair DF, Harshey RM. 2010. The c-di-GMP binding protein YcgR controls flagellar motor direction and speed to affect chemotaxis by a "backstop brake" mechanism. Mol Cell 38:128-139. 
722

723

724

725

726

727

728

729

730

731

732

733

734

735

736

737

738

739

740

741

742

743

744

745

746

747

748

749

750

751

752

753

754

755

756

757

758

60. Boehm A, Kaiser M, Li H, Spangler C, Kasper CA, Ackermann M, Kaever V, Sourjik V, Roth V, Jenal U. 2010. Second messenger-mediated adjustment of bacterial swimming velocity. Cell 141:107-16.

61. Fang X, Gomelsky M. 2010. A post-translational, c-di-GMP-dependent mechanism regulating flagellar motility. Molecular Microbiology 76:1295-1305.

62. Wirebrand L, Österberg S, López-Sánchez A, Govantes F, Shingler V. 2018. PP4397/FlgZ provides the link between PP2258 c-di-GMP signalling and altered motility in Pseudomonas putida. Scientific Reports 8:12205.

63. Baker AE, Diepold A, Kuchma SL, Scott JE, Ha DG, Orazi G, Armitage JP, O'Toole GA. 2016. PilZ domain protein FlgZ mediates cyclic di-GMP-dependent swarming motility Control in Pseudomonas aeruginosa. Journal of Bacteriology 198:1837-1846.

64. Alm R, Bodero A, Free P, Mattick J. 1996. Identification of a novel gene, pilZ, essential for type 4 fimbrial biogenesis in Pseudomonas aeruginosa. J Bacteriol 178:46-53.

65. Guzzo CR, Salinas RK, Andrade MO, Farah CS. 2009. PILZ protein structure and interactions with PILB and the FIMX EAL domain: implications for control of type IV pilus biogenesis. J Mol Biol 393:848-66.

66. Ross P, Weinhouse H, Aloni Y, Michaeli D, Weinberger-Ohana P, Mayer R, Braun S, de Vroom E, van der Marel GA, van Boom JH, Benziman M. 1987. Regulation of cellulose synthesis in Acetobacter xylinum by cyclic diguanylic acid. Nature 325:279281.

67. Morgan JLW, McNamara JT, Zimmer J. 2014. Mechanism of activation of bacterial cellulose synthase by cyclic di-GMP. Nat Struct Mol Biol 21:489-496.

68. Muñoz-Dorado J, Inouye S, Inouye M. 1991. A gene encoding a protein serine threonine kinase is required for normal development of $M$. xanthus, a Gram-negative bacterium. Cell 67:995-1006.

69. Pogue CB, Zhou T, Nan B. 2018. PlpA, a PilZ-like protein, regulates directed motility of the bacterium Myxococcus xanthus. Mol Microbiol 107:214-228.

70. Jakobsen JS, Jelsbak L, Jelsbak L, Welch RD, Cummings C, Goldman B, Stark E, Slater S, Kaiser D. 2004. Sigma54 enhancer binding proteins and Myxococcus xanthus fruiting body development. J Bacteriol 186:4361-8.

71. Black WP, Xu Q, Yang Z. 2006. Type IV pili function upstream of the Dif chemotaxis pathway in Myxococcus xanthus EPS regulation. Mol Microbiol 61:447-56.

72. Sun M, Wartel M, Cascales E, Shaevitz JW, Mignot T. 2011. Motor-driven intracellular transport powers bacterial gliding motility. Proc Natl Acad Sci U S A 108:7559-64.

73. Nan B, Bandaria JN, Moghtaderi A, Sun IH, Yildiz A, Zusman DR. 2013. Flagella stator homologs function as motors for myxobacterial gliding motility by moving in helical trajectories. Proc Natl Acad Sci U S A 110:E1508-13. 
759

760

761

762

763

764

765

766

767

768

769

770

771

772

773

774

775

776

777

778

779

780

781

782

783

784

785

786

787

788

789

790

791

792

793

794

74. Sun H, Shi W. 2001. Genetic studies of $m r p$, a locus essential for cellular aggregation and sporulation of Myxococcus xanthus. J Bacteriol 183:4786-95.

75. Stock AM, Robinson VL, Goudreau PN. 2000. Two-component signal transduction. Annu Rev Biochem 69:183-215.

76. McCleary WR, Zusman DR. 1990. FrzE of Myxococcus xanthus is homologous to both CheA and CheY of Salmonella typhimurium. Proc Natl Acad Sci U S A 87:5898-902.

77. Miertzschke M, Körner C, Vetter IR, Keilberg D, Hot E, Leonardy S, Søgaard-Andersen L, Wittinghofer A. 2011. Structural analysis of the Ras-like G protein MgIA and its cognate GAP MgIB and implications for bacterial polarity. EMBO J 30:4185-4197.

78. Domian IJ, Quon KC, Shapiro L. 1997. Cell type-specific phosphorylation and proteolysis of a transcriptional regulator controls the G1-to-S transition in a bacterial cell cycle. Cell 90:415-424.

79. Klose KE, Weiss DS, Kustu S. 1993. Glutamate at the site of phosphorylation of nitrogen-regulatory protein NTRC mimics Aspartyl-Phosphate and activates the protein. Journal of Molecular Biology 232:67-78.

80. Burckhardt RM, Escalante-Semerena JC. 2020. Small-molecule acetylation by GCN5related acetyltransferases in bacteria. Microbiol Mol Biol Rev 84:e00090-19.

81. VanDrisse CM, Escalante-Semerena JC. 2019. Protein acetylation in bacteria. Annu Rev Microbiol 73:111-132.

82. Nambi S, Basu N, Visweswariah SS. 2010. cAMP-regulated protein lysine acetylases in mycobacteria. J Biol Chem 285:24313-23.

83. Jelsbak L, Søgaard-Andersen L. 2002. Pattern formation by a cell surface-associated morphogen in Myxococcus xanthus. Proc Natl Acad Sci USA 99:2032-2037.

84. Keilberg D, Wuichet K, Drescher F, Søgaard-Andersen L. 2012. A response regulator interfaces between the Frz chemosensory system and the MglA/MglB GTPase/GAP module to regulate polarity in Myxococcus xanthus. PLOS Genet 8:e1002951.

85. Zhang Y, Guzzo M, Ducret A, Li Y-Z, Mignot T. 2012. A dynamic response regulator protein modulates G-protein-dependent polarity in the bacterium Myxococcus xanthus. PLOS Genet 8:e1002872.

86. Shi X, Wegener-Feldbrügge S, Huntley S, Hamann N, Hedderich R, SøgaardAndersen L. 2008. Bioinformatics and experimental analysis of proteins of twocomponent systems in Myxococcus xanthus. J Bacteriol 190:613-624.

87. Kaiser D. 1979. Social gliding is correlated with the presence of pili in Myxococcus xanthus. Proc Natl Acad Sci U S A 76:5952-6.

88. Hodgkin J, Kaiser D. 1977. Cell-to-cell stimulation of movement in nonmotile mutants of Myxococcus. Proc Natl Acad Sci U S A 74:2938-42. 
89. Sambrook J, Russell DW. 2001. Molecular cloning : a laboratory manual, 3rd ed. Cold Spring Harbor Laboratory Press, Cold Spring Harbor, N.Y.

90. Søgaard-Andersen L, Slack FJ, Kimsey H, Kaiser D. 1996. Intercellular C-signaling in Myxococcus xanthus involves a branched signal transduction pathway. Genes Dev 10:740-754.

91. Schneider CA, Rasband WS, Eliceiri KW. 2012. NIH Image to ImageJ: 25 years of image analysis. Nat Methods 9:671-5.

92. Fang X, Ahmad I, Blanka A, Schottkowski M, Cimdins A, Galperin MY, Römling U, Gomelsky M. 2014. GIL, a new c-di-GMP-binding protein domain involved in regulation of cellulose synthesis in enterobacteria. Mol Microbiol 93:439-52.

93. Roelofs KG, Wang J, Sintim HO, Lee VT. 2011. Differential radial capillary action of ligand assay for high-throughput detection of protein-metabolite interactions. Proc Natl Acad Sci U S A 108:15528-33.

94. Kanehisa M, Goto S. 2000. KEGG: kyoto encyclopedia of genes and genomes. Nucleic Acids Res 28:27-30.

95. Finn RD, Coggill P, Eberhardt RY, Eddy SR, Mistry J, Mitchell AL, Potter SC, Punta M, Qureshi M, Sangrador-Vegas A, Salazar GA, Tate J, Bateman A. 2016. The Pfam protein families database: towards a more sustainable future. Nucleic Acids Res:D27985.

96. Pagni M, loannidis V, Cerutti L, Zahn-Zabal M, Jongeneel CV, Hau J, Martin O, Kuznetsov D, Falquet L. 2007. MyHits: improvements to an interactive resource for analyzing protein sequences. Nucleic Acids Res 35:W433-7.

97. Madeira F, Park Ym, Lee J, Buso N, Gur T, Madhusoodanan N, Basutkar P, Tivey ARN, Potter SC, Finn RD, Lopez R. 2019. The EMBL-EBI search and sequence analysis tools APIs in 2019. Nucleic Acids Research 47:W636-W641.

98. Li W, Cowley A, Uludag M, Gur T, McWilliam H, Squizzato S, Park YM, Buso N, Lopez R. 2015. The EMBL-EBI bioinformatics web and programmatic tools framework. Nucleic Acids Res 43:W580-4.

99. Yang ZM, Geng YZ, Xu D, Kaplan HB, Shi WY. 1998. A new set of chemotaxis homologues is essential for Myxococcus xanthus social motility. Mol Microbiol 30:11231130.

100. Wu SS, Kaiser D. 1996. Markerless deletions of pil genes in Myxococcus xanthus generated by counterselection with the Bacillus subtilis sacB gene. J Bacteriol 178:5817-21.

101. Jakobczak B, Keilberg D, Wuichet K, Søgaard-Andersen L. 2015. Contact- and protein transfer-dependent stimulation of assembly of the gliding motility machinery in Myxococcus xanthus. PLoS Genet 11. 
832 102. Julien B, Kaiser AD, Garza A. 2000. Spatial control of cell differentiation in Myxococcus

833 xanthus. Proc Natl Acad Sci USA 97:9098-103.

834 103. Wu SS, Kaiser D. 1997. Regulation of expression of the pilA gene in Myxococcus

835 xanthus. J Bacteriol 179:7748-58.

836

104. Jakovljevic V, Leonardy S, Hoppert M, Søgaard-Andersen L. 2008. PilB and PilT are

837 ATPases acting antagonistically in type IV pili function in Myxococcus xanthus. J Bacteriol 190:2411-2421.

839 105. Lee B, Holkenbrink C, Treuner-Lange A, Higgs PI. 2012. Myxococcus xanthus developmental cell fate production: heterogeneous accumulation of developmental regulatory proteins and reexamination of the role of MazF in developmental lysis. $\mathrm{J}$ Bacteriol 194:3058-68.

843

844

845

846 
bioRxiv preprint doi: https://doi.org/10.1101/2021.03.04.433885; this version posted March 4, 2021. The copyright holder for this preprint (which was not certified by peer review) is the author/funder, who has granted bioRxiv a license to display the preprint in perpetuity. It is made available under aCC-BY-NC 4.0 International license.

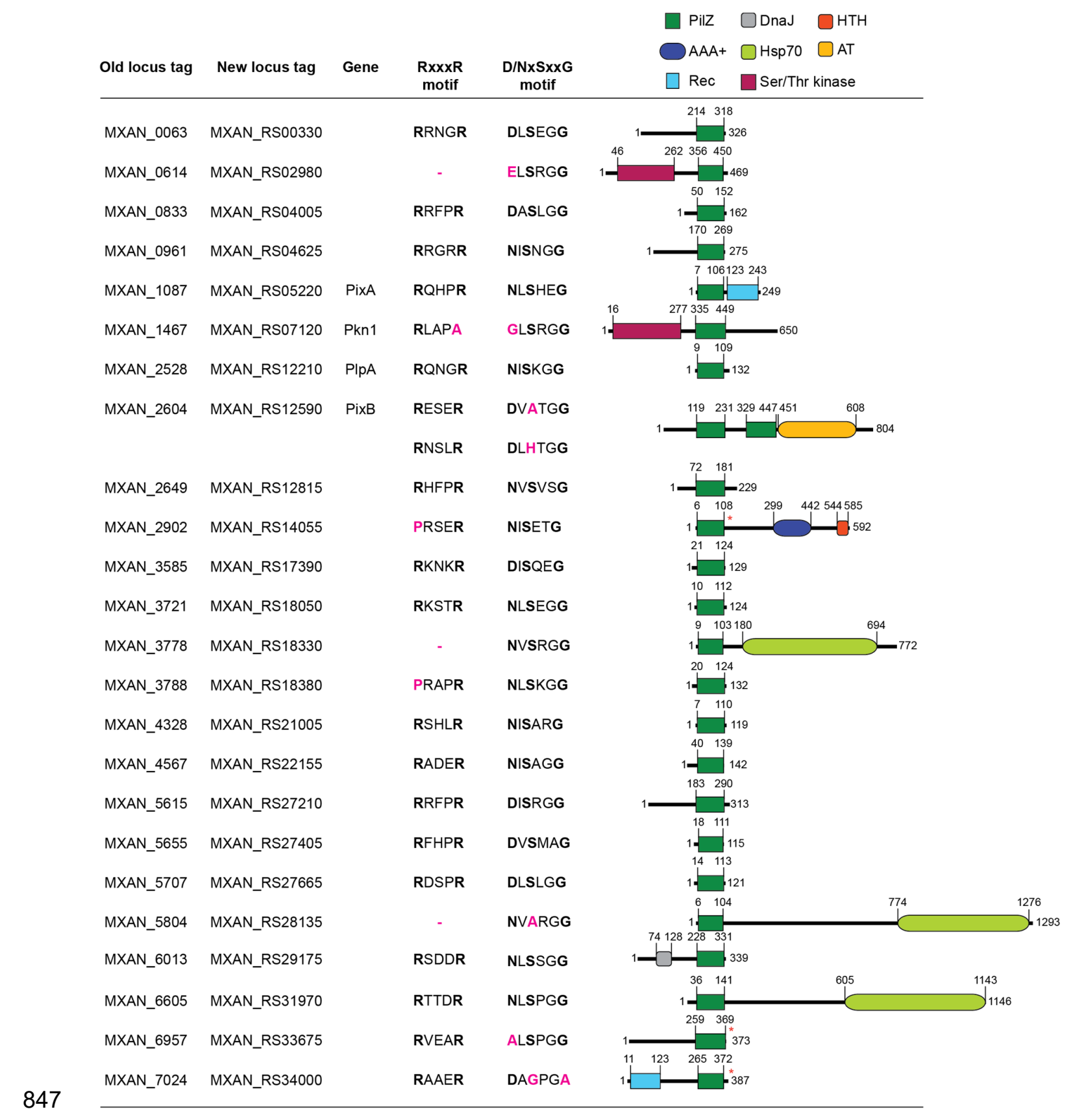

$848 \quad$ Figure 1. Analysis of $M$. xanthus proteins containing a PilZ domain.

849 Domain organization of $M$. xanthus proteins containing a PilZ domain. Locus tags according 850 to the original MXAN annotation of the $M$. xanthus genome and the most recent annotation 851 are included together with names of proteins described in the literature (See text). Protein 852 domains were identified with Pfam, except the PilZ domains marked with a red asterisk, 853 which were identified with Motif Scan (See Materials \& Methods). Domains are drawn to 854 scale. The two conserved sequence motifs involved in c-di-GMP binding are indicated at the 855 top (2); the corresponding amino acid residues are indicated in black if conserved and pink 856 for non-conserved residues. 


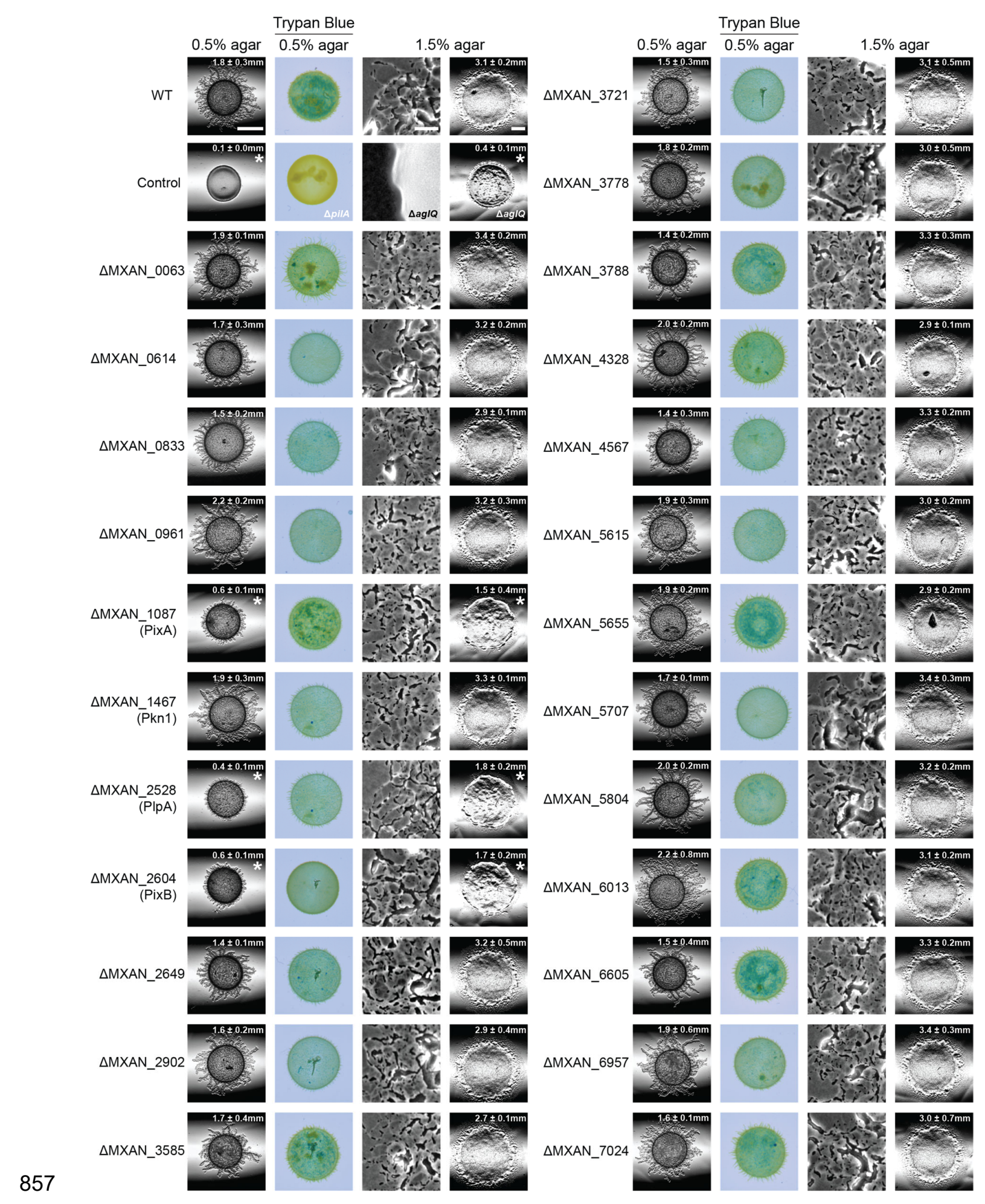

858 Figure 2. Motility assays for mutants lacking individual PilZ domain proteins.

859 T4P-dependent motility and gliding motility were analyzed on $0.5 \%$ agar and $1.5 \%$ agar

860 supplemented with $0.5 \%$ CTT, respectively. Motility was quantified by the increase in colony

861 radius and numbers indicate the mean increase in colony radius \pm standard deviation (SD)

862 from three biological replicates after $24 \mathrm{~h} .{ }^{*}, P<0.05$ in a Student's t test. Scale bars, $3 \mathrm{~mm}$ 
bioRxiv preprint doi: https://doi.org/10.1101/2021.03.04.433885; this version posted March 4, 2021. The copyright holder for this preprint (which was not certified by peer review) is the author/funder, who has granted bioRxiv a license to display the preprint in perpetuity. It is made available under aCC-BY-NC 4.0 International license.

863 (0.5\% agar), $100 \mu \mathrm{m}$ (1.5\% agar, left), $3 \mathrm{~mm}$ (1.5\% agar, right). EPS accumulation was 864 determined on $0.5 \%$ agar supplemented with $0.5 \%$ CTT and $10 \mu \mathrm{g} / \mathrm{ml}$ Trypan Blue.

865 
bioRxiv preprint doi: https://doi.org/10.1101/2021.03.04.433885; this version posted March 4, 2021. The copyright holder for this preprint (which was not certified by peer review) is the author/funder, who has granted bioRxiv a license to display the preprint in perpetuity. It is made available under aCC-BY-NC 4.0 International license.
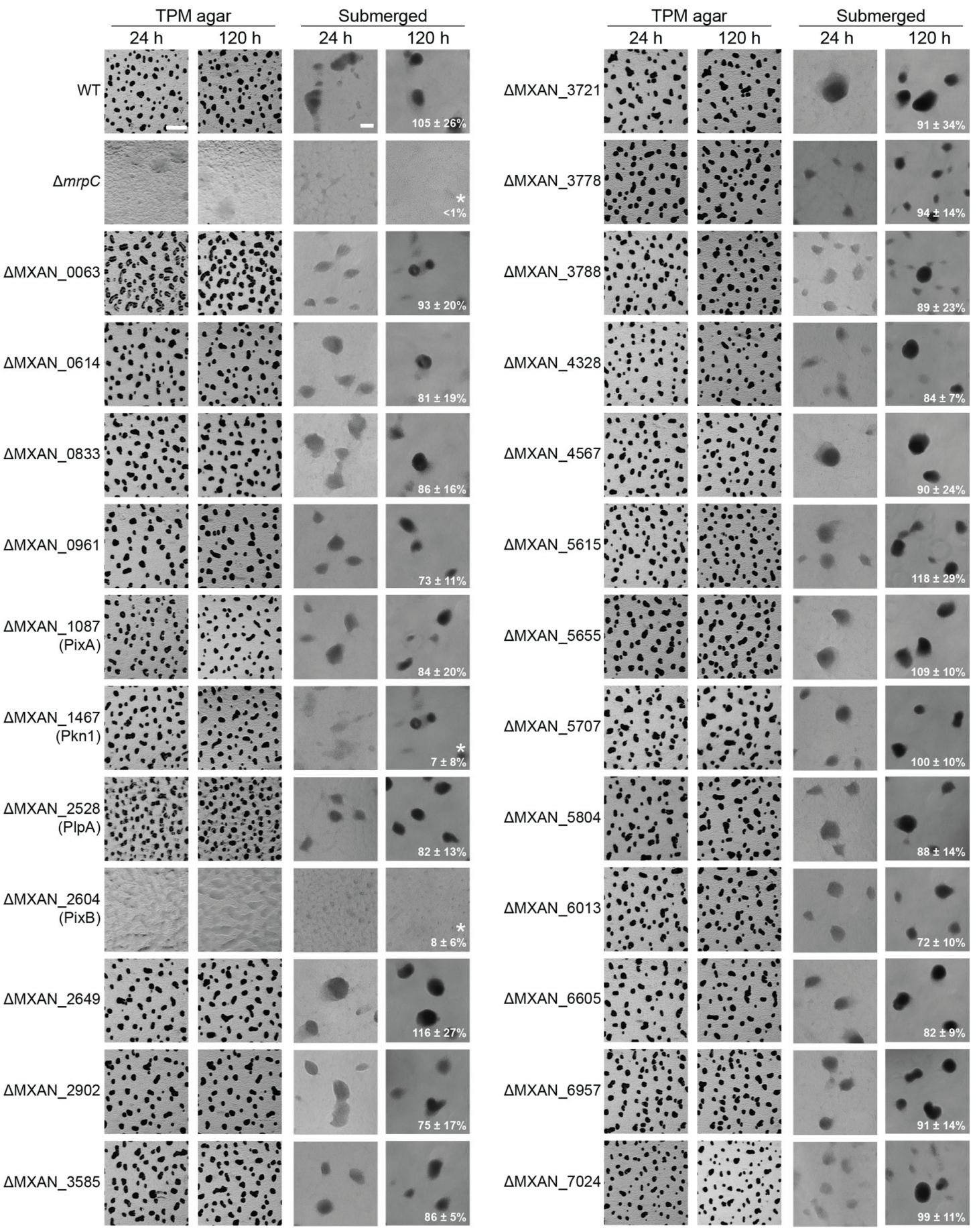

Figure 3. Development assays for mutants lacking individual PilZ domain proteins.

868 Fruiting body formation and sporulation on TPM agar and in MC7 submerged culture.

869 Numbers indicate heat- and sonication resistant spores formed at $120 \mathrm{~h}$ of starvation in

870 submerged culture in percentage of WT $(100 \%) \pm$ SD from three biological replicates. ${ }^{*}, P<$

8710.05 in Student's t test. Scale bars, $500 \mu \mathrm{m}$ (TPM agar), $100 \mu \mathrm{m}$ (submerged). 
bioRxiv preprint doi: https://doi.org/10.1101/2021.03.04.433885; this version posted March 4, 2021. The copyright holder for this preprint (which was not certified by peer review) is the author/funder, who has granted bioRxiv a license to display the preprint in perpetuity. It is made available under aCC-BY-NC 4.0 International license.

A

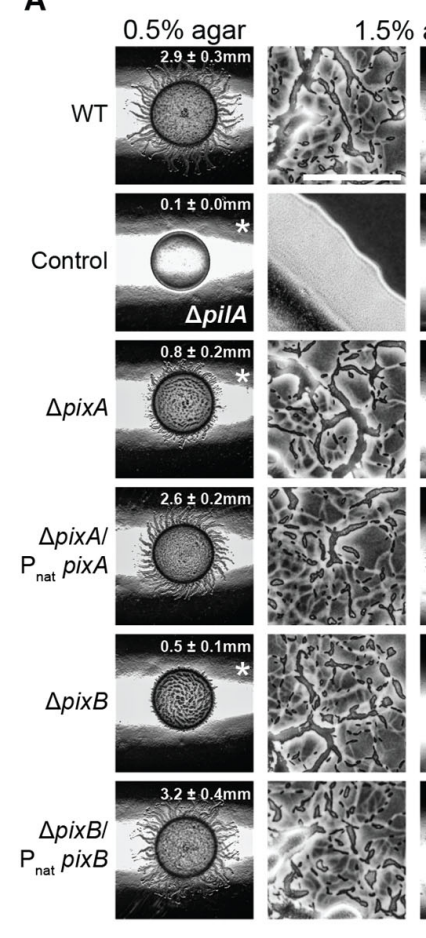

C

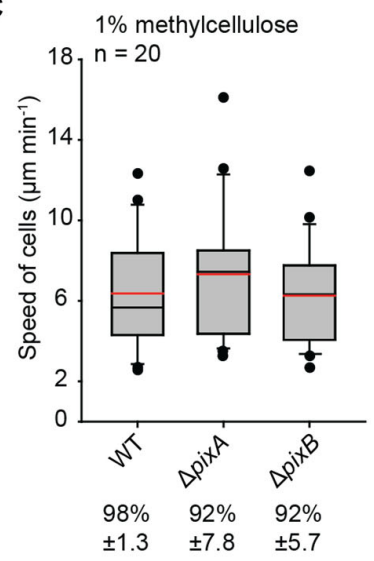

E

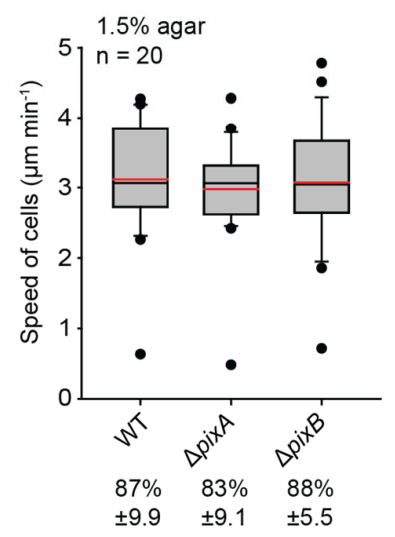

B
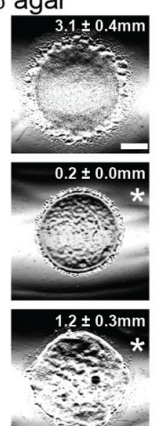

$3.2 \pm 0.2 \mathrm{~mm}$

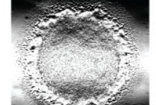

dis.

$1.2 \pm 0.1 \mathrm{~mm}$

$6 *$

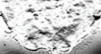

$2.6 .5 \mathrm{~mm}$

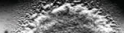

tos

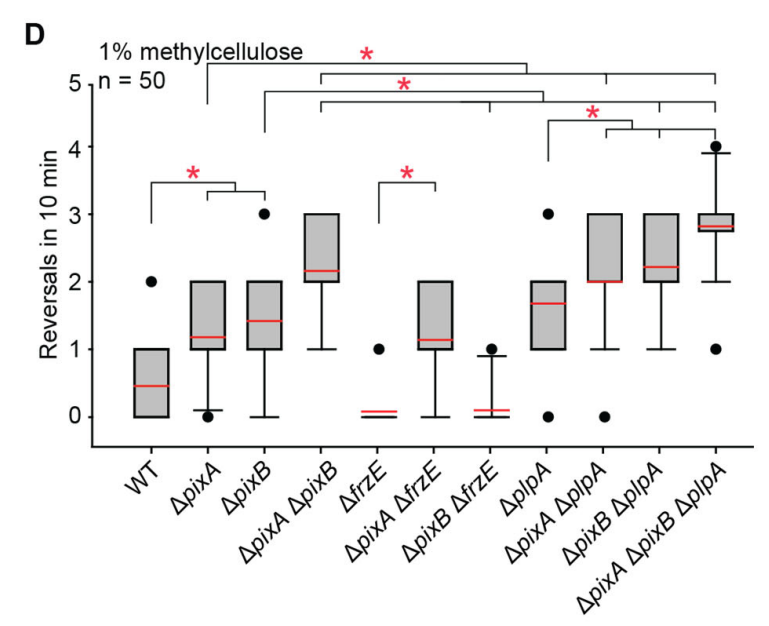

$\mathbf{F}$

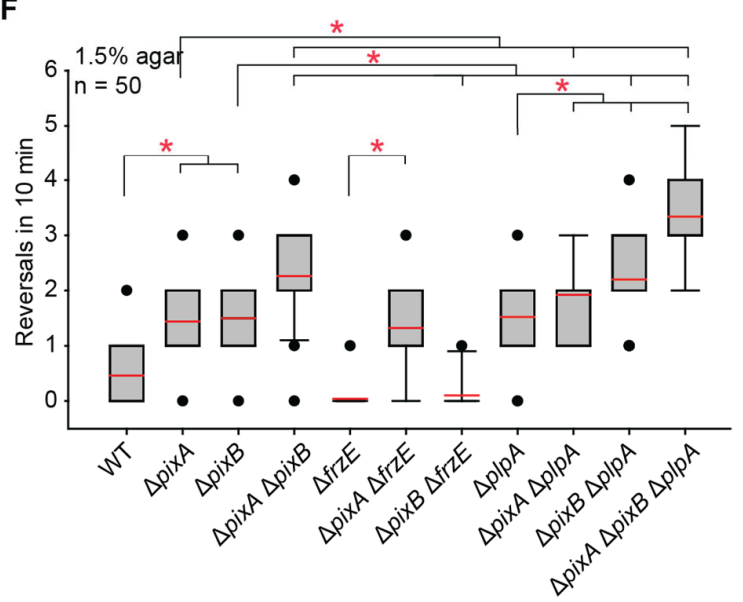

874 A. Complementation of $\triangle$ pixA and $\triangle$ pixB motility defects. Assays were done as in Fig. 2. 
875 Scale bars, $2 \mathrm{~mm}$ (0.5\% agar), $100 \mu \mathrm{m}$ (1.5\% agar, left), $3 \mathrm{~mm}$ (1.5\% agar, right).

876 B. Complementation of $\triangle$ pixB developmental defects. Fruiting body formation and

877 sporulation were analyzed as in Fig. 3. EPS accumulation was determined on TPM agar with

878 addition of Trypan Blue. Numbers indicate heat- and sonication resistant spores formed at

$879120 \mathrm{~h}$ of starvation in submerged culture in percentage of WT $(100 \%) \pm$ SD from three

880 biological replicates. ${ }^{*}, P<0.05$ in Student's t test. Scale bars, $500 \mu \mathrm{m}$ (TPM agar), $100 \mu \mathrm{m}$

881 (submerged).

$882 \mathrm{C}, \mathrm{E}$. Speed of $\triangle$ pixA and $\triangle$ pixB cells in $1 \%$ methylcellulose (C) and on $1.5 \%$ agar

883 supplemented with $0.5 \%$ CTT $(E)$. Boxplots represent the speed of isolated cells per min,

884 boxes enclose the $25^{\text {th }}$ and $75^{\text {th }}$ percentile, whiskers represent the $10^{\text {th }}$ and $90^{\text {th }}$ percentile

885 and dots outliers, red and black line indicates the mean and median, respectively. ${ }^{*} P<0.05$

886 in Mann-Whitney Rank Sum Test, $n=20$ cells. Numbers below indicate the fraction of cells

887 that displayed single cell movement \pm SD.

$888 \mathrm{D}, \mathrm{F}$. Reversal frequency of $\triangle p i x A, \triangle p i x B$ and $\triangle p / p A$ mutants on $1 \%$ methylcellulose (D) and

$8891.5 \%$ agar $(F)$. Boxplots represent the reversals of cells per $10 \mathrm{~min}$. Boxplots are as in $\mathrm{C}$ and

890 E. ${ }^{*} P<0.05$ in Mann-Whitney Rank Sum Test, $\mathrm{n}=50$ cells. 

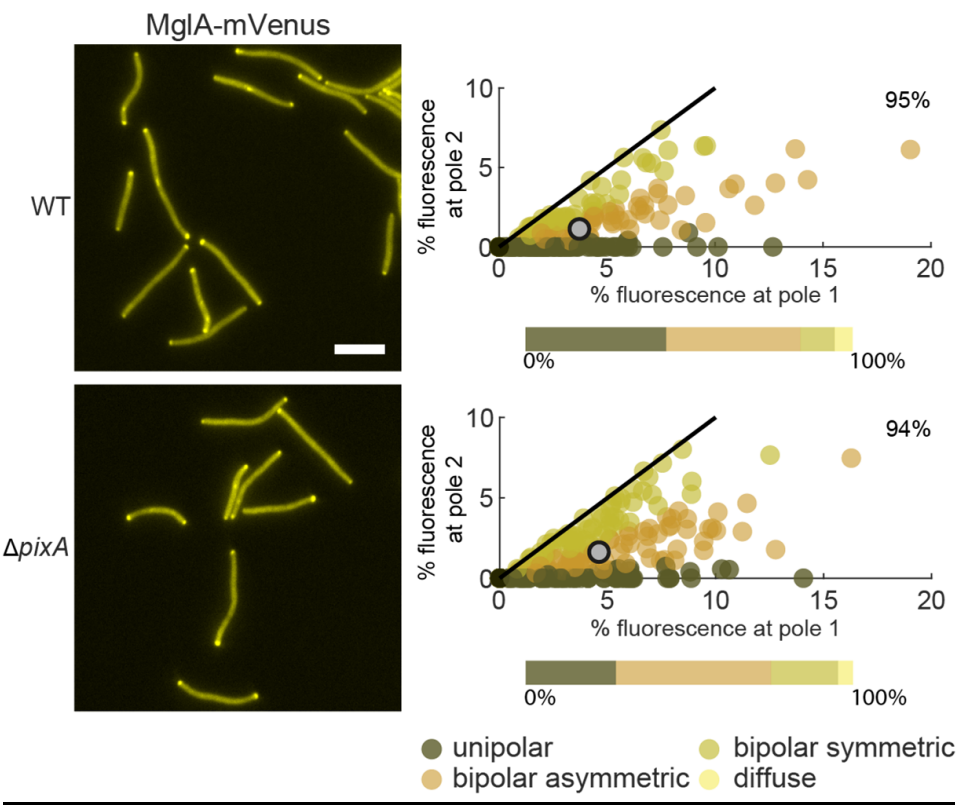

Figure 5. PixA is important for unipolar MglA-mVenus localization

894 For each cell with polar clusters, an asymmetry index was calculated as described in 895 Materials \& Methods to distinguish between unipolar, asymmetric bipolar and symmetric 896 bipolar localization. Cells with no polar signal were categorized as cells with diffuse 897 localization. In the scatter plot, the percentage of total fluorescence at pole 2 is plotted 898 against the percentage of total fluorescence at pole 1 for all cells with polar cluster(s) and 899 individual cells are color-coded according to its localization pattern. Pole 1 is per definition 900 the pole with the highest fluorescence. Black lines are symmetry lines, grey dots show the 901 mean and numbers in the upper right corner are the mean percentage of total fluorescence 902 in the cytoplasm. Horizontal bars show the percentage of cells with polar localization patterns 903 and diffuse localization according to the color code. $n=200$ cells. Scale bar, $5 \mu \mathrm{m}$. 
A
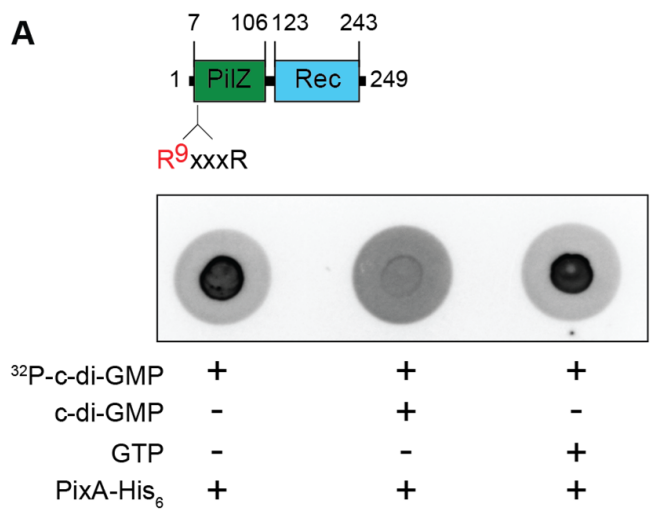

PixA-His $_{6}+$

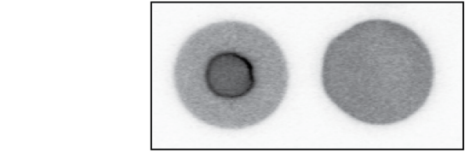

${ }^{32 P-C-d i-G M P}+\quad+$

$\mathrm{PixA}-\mathrm{His}_{6}+$

$906 \quad$ Figure 6. In vitro assay for c-di-GMP binding by PixA and PixB

907 DRaCALA assay to detect specific c-di-GMP binding by purified proteins. Full-length PixA-

$908 \mathrm{His}_{6}$ (A, upper panel), PixA ${ }^{\mathrm{R} 9 \mathrm{~A}}-\mathrm{His}_{6}$ (A, lower panel) or PixB-His ${ }_{6}(\mathrm{~B})$ were incubated at a final 909 concentration of $20 \mu \mathrm{M}$ with ${ }^{32} \mathrm{P}$-labeled c-di-GMP. Unlabeled c-di-GMP and GTP were 910 added to final concentrations of $400 \mu \mathrm{M}$, as indicated. 
bioRxiv preprint doi: https://doi.org/10.1101/2021.03.04.433885; this version posted March 4, 2021. The copyright holder for this preprint (which was not certified by peer review) is the author/funder, who has granted bioRxiv a license to display the preprint in perpetuity. It is made available under aCC-BY-NC 4.0 International license.

A

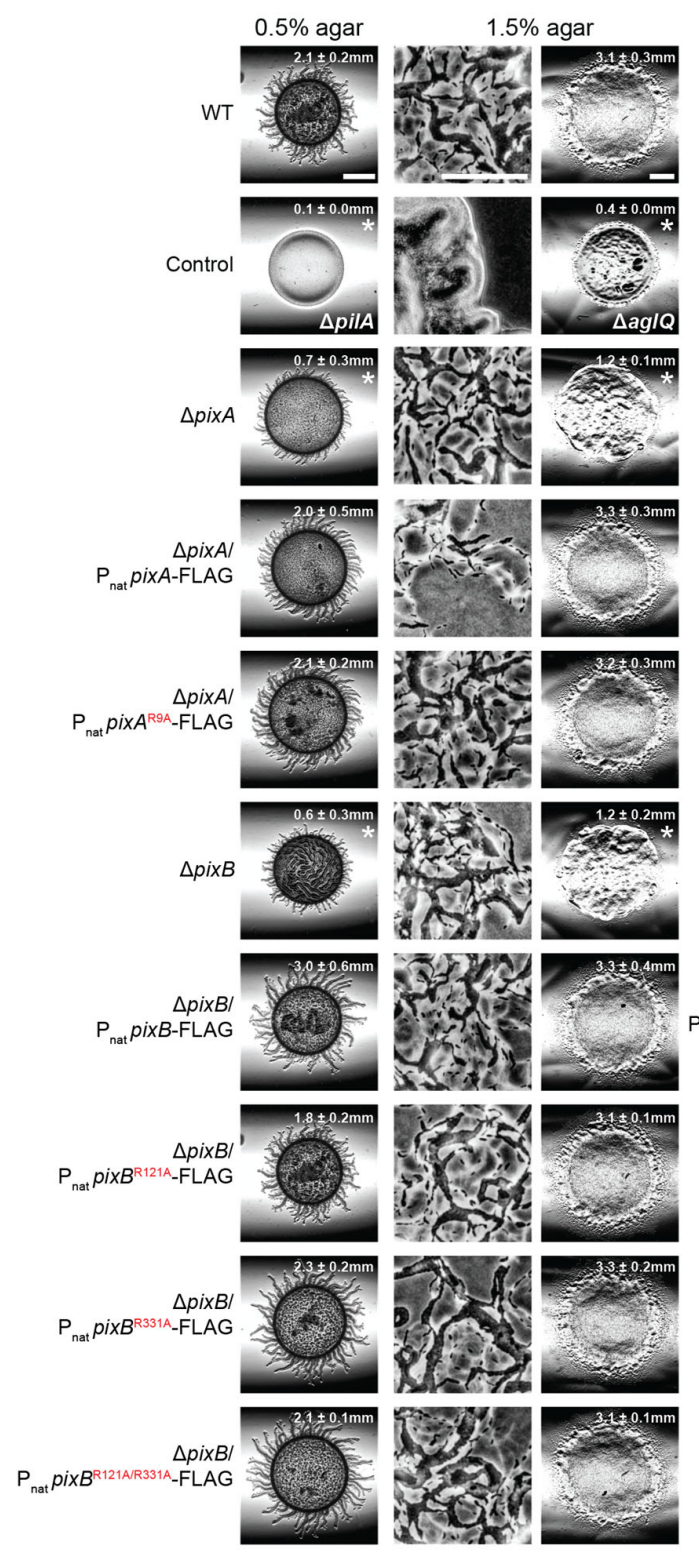

B

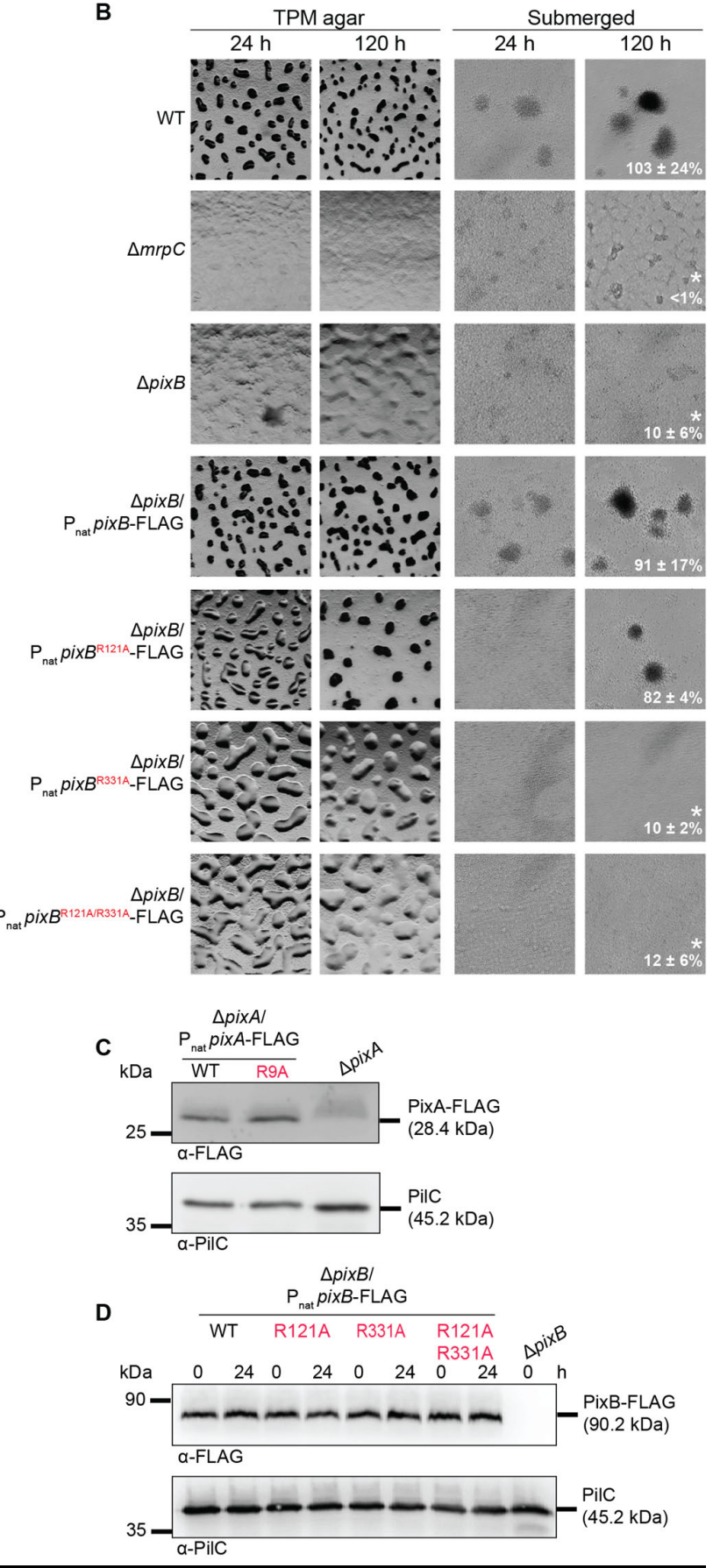

913 Figure 7. Role of c-di-GMP binding by the PixA and PixB PilZ domains in regulation of

914 motility and development

915 A. Motility assays of strains expressing full-length WT or protein variants with a mutated

916 RxxxR motif in the PilZ domains. Motility was analyzed as described in Fig. 2. Scale bars, 3

$917 \mathrm{~mm}$ (0.5\% agar), $100 \mu \mathrm{m}$ (1.5\% agar, left), $3 \mathrm{~mm}$ (1.5\% agar, right).

918 B. Development assays of the $\triangle$ pixB mutant expressing full-length WT or protein variants 919 with a mutated RxxxR motif in PilZ domains. Assays were done as described in Fig. 3. Scale 920 bars, $500 \mu \mathrm{m}$ (TPM agar), $100 \mu \mathrm{m}$ (submerged).

921 C, D. Immunoblot detection of PixA-FLAG (C) and PixB-FLAG (D). For PixA-FLAG samples, 922 total cell extracts were prepared form exponentially grown cells; for PixB-FLAG samples, cell 
bioRxiv preprint doi: https://doi.org/10.1101/2021.03.04.433885; this version posted March 4, 2021. The copyright holder for this preprint (which was not certified by peer review) is the author/funder, who has granted bioRxiv a license to display the preprint in perpetuity. It is made available under aCC-BY-NC 4.0 International license.

923 extracts were prepared form exponentially grown cells and at $24 \mathrm{~h}$ of starvation in 924 submerged culture. $10 \mu \mathrm{g}$ of protein was loaded per lane and samples separated by SDS-

925 PAGE. Upper blots were probed with a-FLAG antibodies and lower blots with a-PilC

926 antibodies. The PilC blots served as loading controls. Molecular mass marker is indicated on 927 the left. 
bioRxiv preprint doi: https://doi.org/10.1101/2021.03.04.433885; this version posted March 4, 2021. The copyright holder for this preprint (which was not certified by peer review) is the author/funder, who has granted bioRxiv a license to display the preprint in perpetuity. It is made available under aCC-BY-NC 4.0 International license.

A

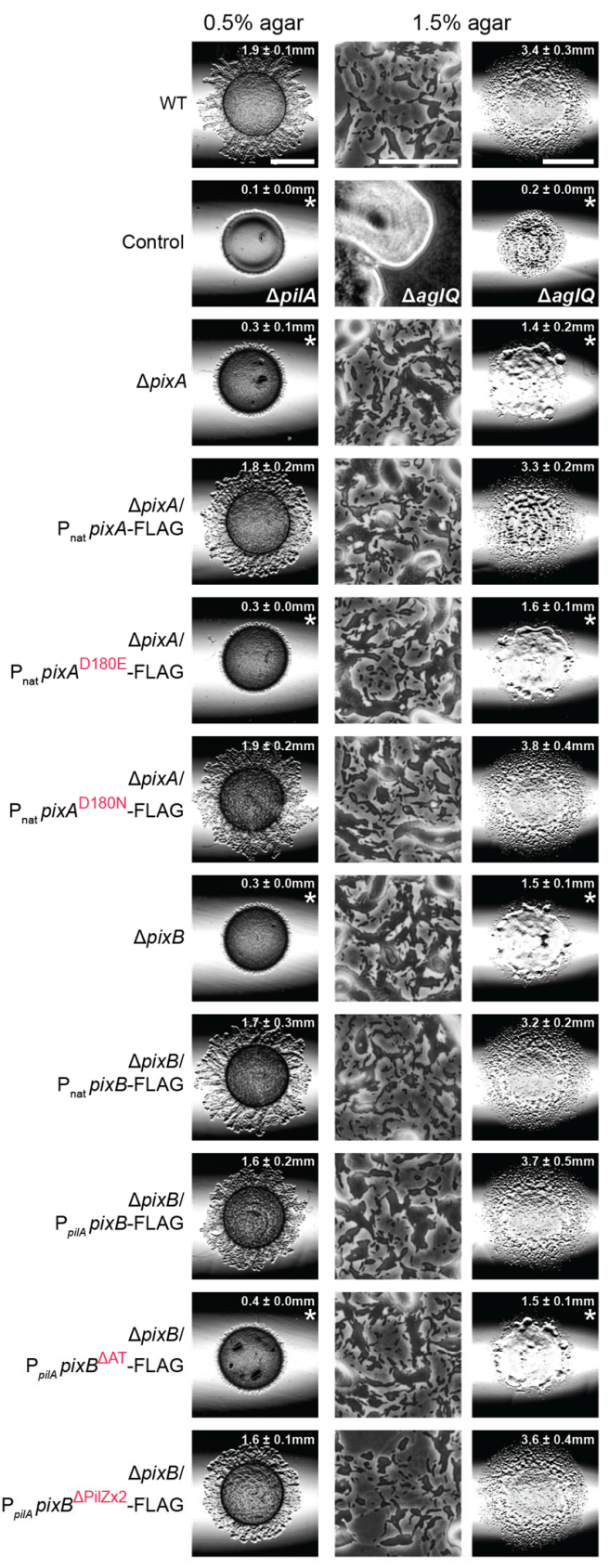

B

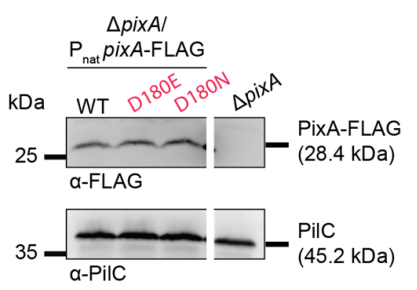

C

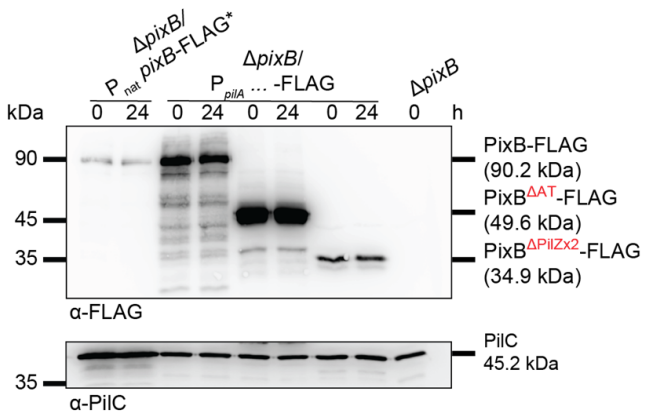

D

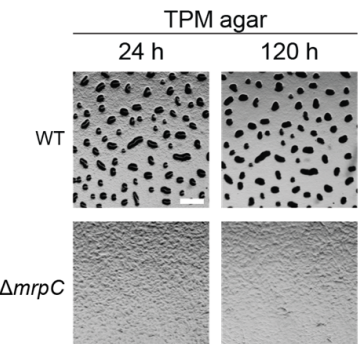

$\frac{\text { Submerged }}{24 \mathrm{~h} 120 \mathrm{~h}}$
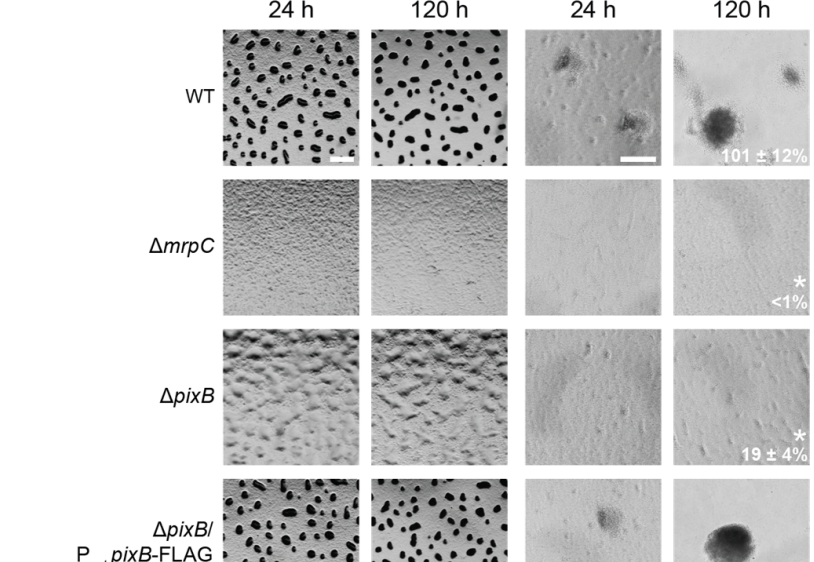

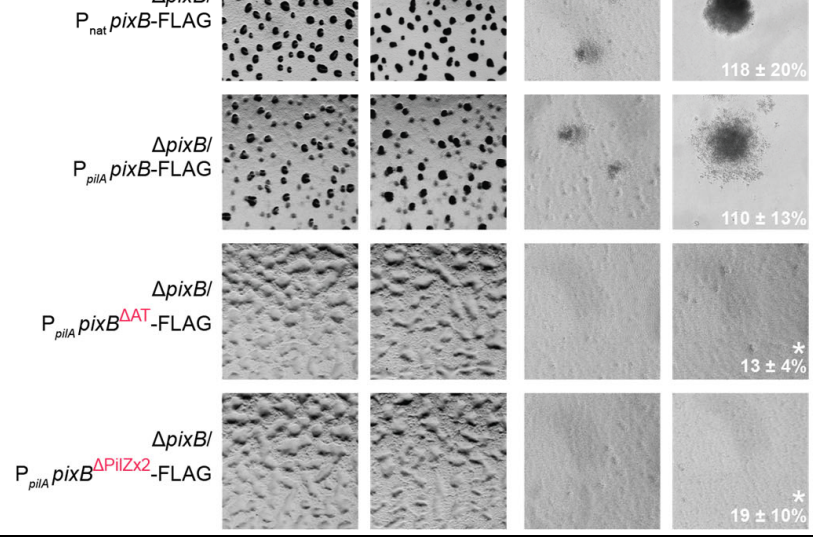

930 Figure 8. Role of PixA receiver domain and PixB AT domain in regulation of motility and

\section{1 development}

932 A. Motility assays of strains expressing mutant variants of PixA and PixB. Motility was

933 analyzed as in Fig. 2. Scale bars, $3 \mathrm{~mm}$ (0.5\% agar), $100 \mu \mathrm{m}$ (1.5\% agar, left), $3 \mathrm{~mm}(1.5 \%$

934 agar, right).

935 B, C. Immunoblot detection of PixA-FLAG (B) and PixB-FLAG (C) variants. Samples were 936 prepared and analyzed as in Fig. 7C, D. In B, samples were loaded on the same gel; the gap 937 indicates lanes that were removed for presentation purposes. $10 \mu \mathrm{g}$ of protein was loaded 
bioRxiv preprint doi: https://doi.org/10.1101/2021.03.04.433885; this version posted March 4, 2021. The copyright holder for this preprint (which was not certified by peer review) is the author/funder, who has granted bioRxiv a license to display the preprint in perpetuity. It is made available under aCC-BY-NC 4.0 International license.

938 per lane except for lanes marked * in which $100 \mu \mathrm{g}$ of protein was loaded and then samples 939 were separated by SDS-PAGE.

940 D. Development assays in strains expressing mutant variants of PixB. Development was

941 analyzed as in Fig. 3. Scale bars, $500 \mu \mathrm{m}$ (TPM agar), $100 \mu \mathrm{m}$ (submerged).

942

943 
944 Table 1. M. xanthus strains used in this study

\begin{tabular}{|c|c|c|}
\hline Strain & Characteristics & Reference \\
\hline DK1622 & wild-type & $(87)$ \\
\hline SW501 & difE::kan ${ }^{R}$ & (99) \\
\hline DK10410 & $\Delta$ pilA & $(100)$ \\
\hline SA5293 & $\Delta a g / Q$ & $(101)$ \\
\hline SA6462 & $\Delta m r p C$ & This study \\
\hline SA8802 & $\Delta f r z E$ & $(50)$ \\
\hline SA8185 & mgIA-mVenus & $(50)$ \\
\hline SA8047 & $\Delta$ pixA mglA-mVenus & This study \\
\hline SA8060 & $\Delta \mathrm{MXAN} 0063$ & This study \\
\hline SA8034 & $\Delta M X A N \_0614$ & This study \\
\hline SA8069 & $\Delta \mathrm{MXAN} 0833$ & This study \\
\hline SA8087 & $\Delta$ MXAN_0961 & This study \\
\hline SA8042 & $\triangle \mathrm{MXAN}$ _1087 (pixA) & This study \\
\hline SA8082 & $\Delta \mathrm{MXAN} \_1467$ (pkn1) & This study \\
\hline SA8509 & $\Delta \mathrm{MXAN} 22528(p / p A)$ & This study \\
\hline SA8811 & $\triangle \mathrm{MXAN} 2604$ (pixB) & This study \\
\hline SA8800 & $\Delta \mathrm{MXAN} 22649$ & This study \\
\hline SA8812 & $\Delta$ MXAN_2902 & This study \\
\hline SA8506 & $\triangle M X A N \_3585$ & This study \\
\hline SA8801 & $\Delta \mathrm{MXAN}=3721$ & This study \\
\hline SA8088 & $\Delta$ MXAN_3778 & This study \\
\hline SA8039 & $\triangle M X A N \_3788$ & This study \\
\hline SA8508 & $\Delta \mathrm{MXAN} \_4328$ & This study \\
\hline SA8078 & $\triangle M X A N$ & This study \\
\hline SA8049 & $\Delta M X A N \_5615$ & This study \\
\hline SA8083 & $\Delta \mathrm{MXAN}=5655$ & This study \\
\hline SA5634 & $\Delta$ MXAN_5707 & This study \\
\hline SA8029 & $\Delta M X A N \_5804$ & This study \\
\hline SA8035 & $\Delta \mathrm{MXAN} \_6013$ & This study \\
\hline SA5639 & $\Delta$ MXAN_6605 & This study \\
\hline SA8050 & $\triangle \mathrm{MXAN} 6957$ & This study \\
\hline SA8040 & $\Delta \mathrm{MXAN} \_7024$ & This study \\
\hline SA8054 & $\triangle$ pixA $\triangle \overline{f r z E}$ & This study \\
\hline SA10130 & $\Delta$ pixB $\Delta$ frzE & This study \\
\hline SA10131 & $\Delta p i x A \Delta p / p A$ & This study \\
\hline SA10132 & $\Delta p i x B \Delta p / p A$ & This study \\
\hline SA10134 & $\triangle$ pixA $\triangle$ pixB & This study \\
\hline SA10139 & $\triangle$ pixA $\triangle$ pixB $\triangle p / p A$ & This study \\
\hline SA8045 & $\Delta$ pixA/P $\mathrm{P}_{\text {nat }}$ pixA & This study \\
\hline SA10120 & $\Delta p i x A / P_{\text {nat }}$ pixA-FLAG & This study \\
\hline SA10121 & $\Delta$ pixA/P ${ }_{\text {nat }}$ pix $A^{\mathrm{R} 9 \mathrm{~A}}$-FLAG & This study \\
\hline SA10136 & $\Delta$ pixA/P ${ }_{\text {nat }}$ pix $A^{\mathrm{D} 180 \mathrm{E}_{-} \mathrm{FLAG}}$ & This study \\
\hline SA10140 & $\Delta$ pixA/P ${ }_{\text {nat }}$ pixA $^{\mathrm{D} 180 \mathrm{~N}}-\mathrm{FLAG}$ & This study \\
\hline SA8829 & $\Delta$ pixB/P $\mathrm{P}_{\text {nat }}$ pixB & This study \\
\hline SA9933 & $\Delta$ pixB/P $\mathrm{P}_{\text {nat }}$ pixB -FLAG & This study \\
\hline SA9935 & $\Delta$ pixB/P $\mathrm{P}_{\text {nat }}$ pixB ${ }^{\mathrm{R} 121 \mathrm{~A}}-\mathrm{FLAG}$ & This study \\
\hline SA9936 & $\Delta$ pixB/P $\mathrm{P}_{\text {nat }}$ pixB R331A $^{\mathrm{R}} \mathrm{FLAG}$ & This study \\
\hline
\end{tabular}


bioRxiv preprint doi: https://doi.org/10.1101/2021.03.04.433885; this version posted March 4, 2021. The copyright holder for this preprint (which was not certified by peer review) is the author/funder, who has granted bioRxiv a license to display the preprint in perpetuity. It is made available under aCC-BY-NC 4.0 International license.

\begin{tabular}{|c|c|c|}
\hline SA9937 & $\Delta$ pixB/P ${ }_{\text {nat }}$ pixB ${ }^{\mathrm{R} 121 \mathrm{~A} / \mathrm{R} 331 \mathrm{~A}}-\mathrm{FLAG}$ & This study \\
\hline SA9941 & $\Delta$ pixB / $P_{\text {pilA }}$ pixB-FLAG & This study \\
\hline SA9940 & $\Delta$ pixB $/ \mathrm{P}_{\text {pilA }}$ pixB $B^{\Delta A T}$-FLAG & This study \\
\hline SA10135 & $\Delta$ pixB $/ \mathrm{P}_{\text {pilA }}$ pixB ${ }^{\Delta \mathrm{PilX \times 2}-\mathrm{FLAG}}$ & This study \\
\hline
\end{tabular}

945 
946 Table 2. Plasmids used in this study

\begin{tabular}{|c|c|c|}
\hline Plasmid & Description & Reference \\
\hline pBJ114 & $\mathrm{Kan}^{\mathrm{R}}$, galK & $(102)$ \\
\hline pSWU30 & attB, Tet $^{R}$ & $(103)$ \\
\hline pSW105 & $a t t B, \mathrm{Kan}^{\mathrm{R}}$ & $(104)$ \\
\hline $\mathrm{pET} 24 \mathrm{~b}(+)$ & expression vector, Kan $^{R}$ & Novagen \\
\hline pAP19 & pBJ114, frzE, in-frame deletion, $\mathrm{Kan}^{\mathrm{R}}$ & $(48)$ \\
\hline pBJ114_mrpC & pBJ114, $m r p C$, in-frame deletion, $\mathrm{Kan}^{\mathrm{R}}$ & $(105)$ \\
\hline pLC20 & $\begin{array}{l}\text { pBJ114, } m g l A-m \text { Venus, gene replacement at } \\
\text { native site, } \operatorname{Kan}^{\mathrm{R}}\end{array}$ & $(50)$ \\
\hline pSK55 & pBJ114, MXAN_0063, in-frame deletion, $\mathrm{Kan}^{\mathrm{R}}$ & This study \\
\hline pSK32 & pBJ114, MXAN_0614, in-frame deletion, Kan $^{R}$ & This study \\
\hline pSK56 & pBJ114, MXAN 0833, in-frame deletion, Kan $^{R}$ & This study \\
\hline pSK57 & pBJ114, MXAN_0961, in-frame deletion, $\mathrm{Kan}^{\mathrm{R}}$ & This study \\
\hline pSK41 & pBJ114, pix $A$, in-frame deletion, $\mathrm{Kan}^{\mathrm{R}}$ & This study \\
\hline pSK93 & pBJ114, pkn1, in-frame deletion, $\mathrm{Kan}^{\mathrm{R}}$ & This study \\
\hline pMP114 & $\mathrm{pBJ} 114$, plpA, in-frame deletion, $\mathrm{Kan}^{\mathrm{R}}$ & This study \\
\hline pES07 & pBJ114, pixB, in-frame deletion, $\mathrm{Kan}^{\mathrm{R}}$ & This study \\
\hline pES02 & pBJ114, MXAN_2649, in-frame deletion, Kan $^{R}$ & This study \\
\hline pES08 & pBJ114, MXAN_2902, in-frame deletion, Kan $^{R}$ & This study \\
\hline pMP115 & pBJ114, MXAN_3585, in-frame deletion, Kan $^{R}$ & This study \\
\hline pES01 & pBJ114, MXAN_3721, in-frame deletion, Kan $^{R}$ & This study \\
\hline pSK42 & pBJ114, MXAN_3778, in-frame deletion, Kan $^{R}$ & This study \\
\hline pSK94 & pBJ114, MXAN_3788, in-frame deletion, Kan $^{R}$ & This study \\
\hline pMP116 & pBJ114, MXAN_4328, in-frame deletion, Kan $^{R}$ & This study \\
\hline pSK58 & pBJ114, MXAN_4567, in-frame deletion, Kan $^{R}$ & This study \\
\hline pSK95 & pBJ114, MXAN_5615, in-frame deletion, Kan $^{R}$ & This study \\
\hline pSK96 & pBJ114, MXAN_5655, in-frame deletion, Kan $^{R}$ & This study \\
\hline pDJS82 & pBJ114, MXAN_5707, in-frame deletion, Kan $^{R}$ & This study \\
\hline pSK34 & pBJ114, MXAN_5804, in-frame deletion, Kan $^{R}$ & This study \\
\hline pSK36 & pBJ114, MXAN_6013, in-frame deletion, Kan $^{R}$ & This study \\
\hline pDJS94 & pBJ114, MXAN_6605, in-frame deletion, Kan $^{R}$ & This study \\
\hline pSK62 & pBJ114, MXAN_6957, in-frame deletion, Kan $^{R}$ & This study \\
\hline pSK37 & pBJ114, MXAN_7024, in-frame deletion, Kan $^{R}$ & This study \\
\hline pSK53 & pSWU30, $\mathrm{P}_{\text {nat }}$ pix $A$, attB, Tet $^{\mathrm{R}}$ & This study \\
\hline pSK139 & pSWU30, $\mathrm{P}_{\text {nat }}$ pixA-FLAG, attB, Tet $^{\mathrm{R}}$ & This study \\
\hline pSK140 & pSWU30, $\mathrm{P}_{\text {nat }}$ pixA $A^{\mathrm{R} 9 \mathrm{~A}}-\mathrm{FLAG}$, attB, Tet $^{\mathrm{R}}$ & This study \\
\hline pSK144 & pSWU30, $\mathrm{P}_{\text {nat }}$ pixA ${ }^{\mathrm{D} 180 \mathrm{E}}-\mathrm{FLAG}$, attB, Tet $^{\mathrm{R}}$ & This study \\
\hline pSK145 & pSWU30, $\mathrm{P}_{\text {nat }}$ pixA ${ }^{\mathrm{D} 180 \mathrm{~N}}-\mathrm{FLAG}$, attB, $_{\text {Tet }}{ }^{\mathrm{R}}$ & This study \\
\hline pES12 & pSWU30, $P_{\text {nat }}$ pixB, attB, Tet $^{R}$ & This study \\
\hline pPK11 & pSWU30, $P_{\text {nat }}$ pixB-FLAG, attB, Tet $^{R}$ & This study \\
\hline pPK13 & pSWU30, $P_{\text {nat }}$ pixB ${ }^{R 121 A}-F L A G$, attB, Tet $^{R}$ & This study \\
\hline pPK14 & pSWU30, $P_{\text {nat }}$ pixB ${ }^{\mathrm{R} 331 \mathrm{~A}}-\mathrm{FLAG}$, attB, Tet $^{\mathrm{R}}$ & This study \\
\hline pPK15 & 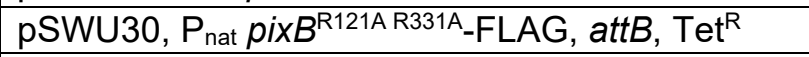 & This study \\
\hline pPK18 & pSW105, $\mathrm{P}_{\text {pilA }}$ pixB-FLAG, attB, $\mathrm{Kan}^{\mathrm{R}}$ & This study \\
\hline pPK17 & pSW105, $\mathrm{P}_{\text {pilA }}$ pixB ${ }^{\Delta A T}$-FLAG, attB, $\mathrm{Kan}^{\mathrm{R}}$ & This study \\
\hline pSK143 & pSW105, $\mathrm{P}_{\text {pilA }}$ pixB ${ }^{\Delta \mathrm{PilZx2}}-\mathrm{FLAG}$, attB, $\mathrm{Kan}^{\mathrm{R}}$ & This study \\
\hline pSK51 & pET24b(+), pixA-His $6, \mathrm{Kan}^{\mathrm{R}}$ & This study \\
\hline pSK141 & pET24b(+), pixA ${ }^{\mathrm{R} 9 \mathrm{~A}}-\mathrm{His}_{6}, \mathrm{Kan}^{\mathrm{R}}$ & This study \\
\hline
\end{tabular}


bioRxiv preprint doi: https://doi.org/10.1101/2021.03.04.433885; this version posted March 4, 2021. The copyright holder for this preprint (which was not certified by peer review) is the author/funder, who has granted bioRxiv a license to display the preprint in perpetuity. It is made available under aCC-BY-NC 4.0 International license.

\begin{tabular}{|c|c|c|}
\hline pES09 & pET24b(+), pixB-His $6, \mathrm{Kan}^{\mathrm{R}}$ & This study \\
\hline pPK21 & pET24b(+), pixB ${ }^{\mathrm{R} 121 \mathrm{~A}}-\mathrm{His}_{6}, \mathrm{Kan}^{\mathrm{R}}$ & This study \\
\hline pES13 & pET24b(+), pixB ${ }^{\mathrm{R} 331 \mathrm{~A}}-\mathrm{His}{ }_{6}, \mathrm{Kan}^{\mathrm{R}}$ & This study \\
\hline pPK22 & $\mathrm{pET} 24 \mathrm{~b}(+)$, pixB $^{\mathrm{R} 121 \mathrm{~A} / \mathrm{R} 331 \mathrm{~A}}-\mathrm{His}_{6}, \mathrm{Kan}^{\mathrm{R}}$ & This study \\
\hline
\end{tabular}

947

948 